\title{
THE DISTRIBUTION, STATUS AND HABITAT ASSOCIATIONS OF MOOSE IN MAINLAND NOVA SCOTIA
}

\author{
TAMAINI V. SNAITH AND KAREN F. BEAZLEY* \\ School for Resource and Environmental Studies, \\ Dalhousie University, \\ Halifax, Nova Scotia, Canada B3H 3/5
}

\begin{abstract}
Throughout the Nova Scotia mainland, small and fragmented moose populations remain at varying densities and may be limited or regulated by a number of factors including interspecific competition, disease, habitat alteration/loss, mineral toxicity/deficiency, predation, poaching, and resource availability. Ranging behaviour and habitat requirements vary according to environmental factors; however, moose require food and cover in sufficient quantity and of appropriate interspersion to meet their daily and seasonal needs. Mature forest with a well developed understory, and open areas with early successional vegetation provide forage, while dense forest provides cover from thermal stress and deep snow. Strategies for moose conservation, such as through forest management, should concentrate on the preservation and enhancement of habitat to meet the critical requirements of viable moose populations and the re-establishment of connections among discrete populations.
\end{abstract}

\begin{abstract}
Sur la terre ferme en Nouvelle-Écosse, il reste de petites populations fragmentées d'orignaux de densités variables qui sont peut-être limitées ou régulées par plusieurs facteurs dont la compétition interspécifique, les maladies, l'altération ou la destruction des habitats, la toxicité des minéraux ou le manque de minéraux, la prédation, le braconnage et la disponibilité des ressources. Les déplacements et les besoins en matière d'habitat des orignaux varient en fonction des facteurs environnementaux; cependant, les orignaux ont besoin de nourriture et d'un couvert adéquatement répartis pour satisfaire leurs besoins quotidiens et saisonniers. Les forêts matures à sous-étage bien développé et les zones ouvertes caractérisées par des espèces végétales pionnières fournissent la nourriture, tandis que les forêts denses offrent un couvert contre le stress thermique et la neige épaisse. Les stratégies de conservation des orignaux, par exemple associées à l'aménagement des forêts, devraient viser principalement la conservation et l'amélioration de l'habitat de manière à combler les besoins essentiels des populations viables d'orignaux, ainsi que le rétablissement de la connectivité entre les populations disjointes.
\end{abstract}

\section{Introduction}

Over the past few centuries, Nova Scotia has undergone extensive habitat conversion, degradation, and fragmentation as a result of increasing urbanization, argricultural development, and resource extraction. As a consequence of human exploitation and habitat loss, many elements of Nova Scotia's biodiversity are at risk and a number of local species have become endangered or extirpated (COSEWIC 2000). Mainland moose (Alces alces americana) are among the species at risk in Nova Scotia (CESCC 2001). To understand current threats to moose, and to plan for their conservation, it is necessary to determine the status and distribution of populations throughout the province, to understand the habitat relationships of the species, and to examine the range of factors which may be threatening or regulating the population. Little is published describing the population dynamics and habitat associations of moose in Nova Scotia, and to date there has been no attempt to synthesize what is known in Nova Scotia with information gathered from moose populations elsewhere. Thus, the purpose of this paper is to synthesize the available information describing the distribution and status of moose in mainland Nova Scotia, their critical habitat requirements, and factors contributing to their decline. 


\section{Moose Distribution in Nova Scotia}

Historically, moose were abundant throughout Nova Scotia; however, there have been fluctuations and general declines in moose numbers since the early seventeenth century (Dodds 1963, Pulsifer \& Nette 1995). By the early twentieth century, moose were completely extirpated from Cape Breton, and reduced to a few localized populations on the mainland (Pulsifer \& Nette 1995). When indigenous moose failed to recover in Cape Breton, 18 individuals (A.a. andersoni) were introduced from Alberta in 1948/49 and the population increased steadily to about 4000 individuals by the late 1980s (Dodds 1963, Kelsall 1987, Pulsifer 1995, Pulsifer \& Nette 1995, Timmermann \& Buss 1997). Currently, there may be more than 5000 moose in Cape Breton (Nette 2000). During the same period, remnants of the indigenous moose herd on the mainland continued to decline, and now moose remain in significant numbers in only two areas (Figure I) (Pulsifer \& Nette 1995, Nette 2000, Pulsifer 2000, Hall 2000). The northeastern mainland population, concentrated mainly in the Cobequid Highlands, consists of around 500 individuals (possibly as many as 800) but is thought to be declining, while the southwest population is thought to be stable at around 300 individuals, with its core occupying the Tobeatic region. In addition, there are scattered pockets of moose throughout much of the mainland, including no more than 100 individuals in the Pictou/Antigonish Highlands. Currently, the total population on the mainland is about 1000 individuals (Kelsall 1987, Pulsifer \& Nette 1995, Nette 2000, Pulsifer 2000, Hall 2000). Due to the small and fragmented nature of the population, mainland Nova Scotia moose are at risk of extirpation, and have been red-listed in the province (CESCC 2001). In light of this present threat, the focus of this paper is on mainland moose populations.

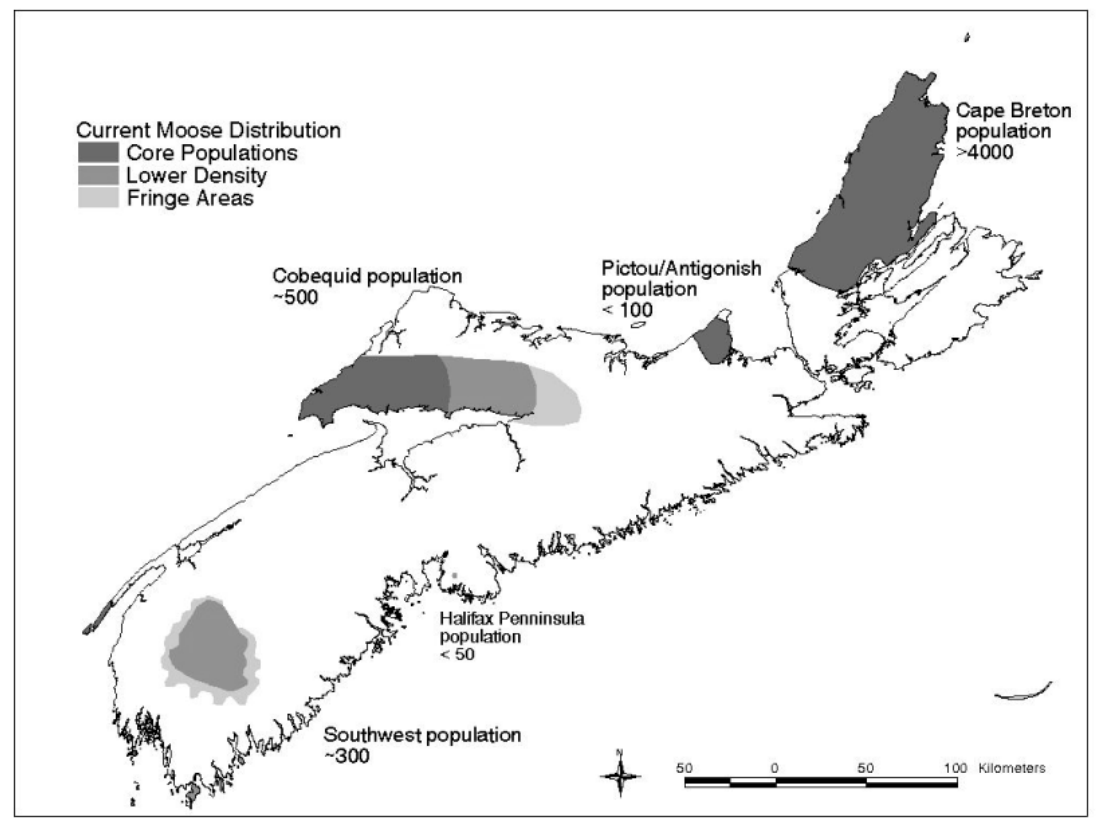

Fig 1 Current Moose Distribution in Nova Scotia 


\section{Moose Habitat Requirements}

Moose require large areas and a diverse landscape to provide the resources essential for their survival (Appendix 1). The specific habitat requirements of moose in Nova Scotia have not been documented in detail. A synthesis of available information, in addition to data from populations elsewhere, will provide useful information about habitat use, ranging behaviour, and area requirements. The following sections summarize what is known about the nutritional, cover and habitat area requirements of moose, and the data is applied to the bioclimatic conditions of Nova Scotia.

\section{Nutritional Requirements}

Early successional deciduous vegetation is the primary source of moose forage, particularly during the spring and summer (see Appendices 1, 2 and 3 for references). The understory of mature forest and open areas following disturbance such as windthrow, insect damage, wildfire or forest harvesting often contain good moose forage. During the summer, moose consume a variety of terrestrial and aquatic foods including deciduous leaves, shrubs, grasses, forbs, aquatic vegetation, and young plant growth high in digestible energy and protein (Regelin et al. 1987, Timmermann \& McNicol 1988). During this time, energy is required for lactation, growth, antler production, and fat storage to ensure winter survival (Timmermann \& McNicol 1988).

During the winter, food intake generally decreases because food resources are limited to poorly digestible woody browse of low nutritional quality, and may be difficult to access due to snow cover and thermal stress (Coady 1974, Belovsky 1981, Schwab 1985, Schwartz et al. 1987, DelGiudice et al. 1997). Conifer consumption is likely dependent on the amount of deciduous browse available, becoming increasingly important as winter progresses or in areas where preferred species are less prevalent (NSDLF undated, Benson 1957, Knowlton 1960, Des Meules 1964, Prescott 1968, Telfer 1984, Cederlund \& Markgren 1987, Timmermann \& McNicol 1988, Histol \& Hjeljord 1993).

Important food species in Nova Scotia include red, sugar, and mountain maple, white and yellow birch, hazelnut, and balsam fir (Appendix 2) (Benson 1957, Telfer 1967a, b, Prescott 1968, Basquille \& Thompson 1997). In Nova Scotia, quantitative field studies have demonstrated that moose rely on maples for up to $50 \%$ of their winter diets, and birch for approximately 20\% (Telfer 1967b, Prescott 1968). Mountain maple is the most important food species and is browsed heavily whenever available (Prescott 1968). The amount of balsam fir consumed varies from very little to $50 \%$ of the diet or more (Benson 1957, Telfer 1967a, b, Prescott 1968, Basquille \& Thompson 1997).

Aquatic vegetation is an important component of moose summer diets in many areas (see Appendix 1 for references). However, wetlands are infrequent in the Cobequid area, and aquatic systems in the southwestern region are generally too acidic to support much vegetation (Morash 2000, Nette 2000). Moose have nevertheless historically persisted in these areas, suggesting that aquatic vegetation is not a critical dietary requirement in Nova Scotia (Telfer 1984).

Based on food species preferences and the vegetative characteristics of Nova Scotia (Loucks 1962, Rowe 1972, Ecological Stratification Working Group 1995, NSDOE 2000, Nette 2000), the Cobequid moose population occupies highly suitable habitat containing a wide variety of preferred hardwood species and occasional wetlands containing aquatic forage. The southwestern population inhabits a less-than-ideal area where the rocky barrens contain fewer hardwood species and are less productive due to poor soils. Although lakes and wetlands are more frequent than in the Cobequid region, aquatic vegetation is limited due to high levels of wetland acidity. 


\section{Cover Requirements}

Vegetative cover is a critical element of moose habitat during all seasons and is necessary for thermoregulation and protection from sun, snow, wind, extreme cold, and predators. Thermal cover (closed-canopy, dense, mature forest at least 30 years old) is necessary to protect moose from heat stress because although moose are well-adapted to cold weather, they are sensitive to hot temperatures (Peterson 1955, Coady 1974, Renecker \& Hudson 1986, Schwab \& Pitt 1991).

Due to thermal radiation, moose cannot comfortably withstand temperatures above approximately 14 to $20^{\circ} \mathrm{C}$ in the summer and -5 to $0^{\circ} \mathrm{C}$ in the winter (Renecker \& Hudson 1986). When temperatures reach these levels, moose restrict their activity and seek cooler micro-environments under dense forest cover or in water bodies (see Appendix 1 for references). Average summer temperatures in Nova Scotia reach about $15^{\circ} \mathrm{C}$ (Ecological Stratification Working Group 1995), which is within the critical range and is probably enough to necessitate the presence of forest cover throughout the summer months. An on-going study of moose in the Tobeatic indicates that moose preferentially select dense, mature deciduous forest habitat during the summer months (Nette 2000). The average winter temperatures of $-1.5^{\circ} \mathrm{C}$ in the southwestern region and -2.5 to $-5.5^{\circ} \mathrm{C}$ in the Cobequids (Ecological Stratification Working Group 1995) are well within the critical range and will create heat stress during the winter, forcing moose to seek shelter from thermal radiation.

In addition to thermal/heat stress, moose require cover to avoid extreme cold and deep snow conditions. As winter progresses moose move into mature conifer-dominated stands which provide the greatest protection from snow, cold, and heat. In Nova Scotia, moose move to sheltered areas during late winter regardless of snow conditions (which rarely reach critical conditions), presumably to alleviate thermal stress (Nette 2000). Moose winter concentration areas, or yards, in the Cobequid Hills of Nova Scotia were described by Prescott (1968) and Telfer (1967a, b) as the most intensively used portions of moose winter range. They are located on the upper third (at $120 \mathrm{~m}$ to $180 \mathrm{~m}$ elevation above sea level) of south-facing slopes where temperatures are mild, and are selected for forage availability as well as dense forest cover for snow, wind, and sun protection. The yards are located where the softwood slopes meet the hardwood hilltops which provides a high diversity of vegetation types and the necessary combination of food and shelter.

Security cover (dense vegetation at least $2 \mathrm{~m}$ high) is essential year-round to escape predators and for successful reproduction and calf-rearing (Knowlton 1960, Thompson \& Euler 1987, Miquelle et al. 1992, Nette 2000). Cows seek secluded areas for calving, such as isolated patches of dense vegetation and islands or peninsulas which offer security from predators (Peterson 1955, LeResche et al. 1974, Taylor \& Ballard 1979, Towry 1984, Leptich \& Gilbert 1986, Allen et al. 1987, Cederlund et al. 1987, Timmermann \& McNicol 1988, Miquelle et al. 1992, Puttock et al. 1996, Bowyer et al. 1999). Calving sites are typically close to open areas with high forage availability, are well sheltered from predator attack, and are near a source of water (Bowyer et al. 1999, Leptich \& Gilbert 1986, Allen et al. 1987). Lowland bogs, islands, or peninsulas with thick cover are ideal and will provide protection for vulnerable calves. Water bodies provide drinking water, refuge from flies and predators, and a cooling mechanism during the hot summer months (van Ballenberghe \& Peek 1971, Peek et al. 1976, 1987, Dunn 1976, Kearney \& Gilbert 1976, Telfer 1984, Ackerman 1987, Joyal 1987, Timmermann \& McNicol 1988, Bontaites \& Gustafson 1993).

The Cobequid region, with frequent densely forested areas, and varied topography where mild microhabitat conditions can usually be found, likely provides habitat with 
adequate cover for moose. In the more barren southwestern region, moose must rely on less frequent and less dense forest stands for cover, but have greater access to water bodies.

\section{Seasonal Habitat Selection}

Based on the literature, the habitat requirements of moose in Nova Scotia can be summarized as follows:

Spring and early summer (April to early June): Moose require open or disturbed areas with lots of good quality forage, calving areas, and forest cover for thermal and predator protection. If available, aquatic vegetation may provide essential nutrients. Mixed habitat providing a combination of food, cover, and water bodies will provide good moose range during the spring and early summer.

Summer (mid-June to early September): During the hottest months of summer, moose require dense forest cover for protection from heat stress, and forage-rich areas which will provide enough food for growth, lactation, and fat storage requirements. Forest edges and open areas in close proximity to dense cover will provide good forage and easily accessible protection from solar radiation. Aquatic sites (for food, escape, and cooling) may be important habitat components during the summer. However, the availability of good aquatic resources is limited in Nova Scotia. Good summer habitat contains an interspersion of densely forested stands and forage producing areas such as mixed or disturbed forests with relatively open canopies or mature forests with understory for forage production.

Fall and early winter (mid-September to early January): Moose will continue making use of forage-rich areas as long as weather and snow conditions allow. Cover is less important during this time because solar radiation decreases and snow does not reach critical levels. Open and disturbed habitat with early successional vegetation is preferred during the fall and early winter.

Late winter (mid-January to late March): Dense cover again becomes critical during the late winter as snow accumulates and temperatures become extreme. Heat stress due to solar radiation, along with wind chill and deep snow, can restrict moose to densely forested areas during the late winter season. The best winter habitat will also include an interspersion of forage-rich areas such as small disturbances and forest edges.

\section{Effects of Forest Disturbance and Management on Moose Habitat}

Forest disturbances result in canopy openings which allow light penetration and natural regeneration (McNicol 1990). Early successional vegetation resulting from disturbances provides good moose forage and moose are often found at their greatest densities in areas where disturbance has occurred (Peterson 1955, Peek 1974a, Peek et al. 1976, Oldemeyer \& Regelin 1987, McNicol 1990). Favourable browsing conditions exist in regenerating stands of about 5 to 40 years old, with a peak around 7 to 15 years post-disturbance (see Appendix 3 for references). Suitable cover, however, will not return for at least 30 years post-disturbance (Telfer 1970b). It is therefore essential to maintain residual stands of cover adequately dispersed throughout disturbed areas.

\section{Natural Disturbance Regimes}

Natural disturbance regimes can provide sufficient moose forage effectively inter- 
spersed with dense forest cover. Small-scale natural disturbances in mature forest continually open up the canopy and produce good understory vegetation which provides excellent forage (Houston 1968, McNicol \& Gilbert 1987, Oldemeyer \& Regelin 1987, Heikkila et al. 1996). Riparian habitat and floodplains undergo constant disturbance and succession, providing forage on a permanent basis (Houston 1968, Peek 1974a, Sumanik \& Demarchi 1977, Doerr 1983, Oldemeyer \& Regelin 1987, MacCracken et al. 1997).

Wildfire may kill or force some animals out of their range, but normally leads to browse improvement and better interspersion and heterogeneity of resources (Dodds 1974, Crawford 1993). Small burns are generally beneficial; however, severe and repeated burning can be detrimental to moose range and has produced areas of ericaceous vegetation in western Nova Scotia which are poor quality moose habitat (Dodds 1974, Muise 2000).

Forest diseases and insect damage, such as birch die-back and spruce budworm (Choristoneura fumiferana) infestations, can lead to habitat degradation through partial or complete defoliation (Prescott 1968, Dodds 1974). Such disturbance leads to regeneration, however, and is often beneficial to moose range by producing early successional vegetation interspersed with sufficient cover (Prescott 1968, Dodds 1974, Crawford 1993). A spruce budworm infestation in the Cape Breton Highlands led to regeneration of preferred forage species, while sufficient thermal cover was maintained, and is associated with a large increase in moose densities in the area (Basquille \& Thompson 1997).

\section{Forest Management}

Forest management can enhance or degrade habitat for moose. For example, regenerating clearcuts provide good moose browse after 10 to 40 years; however, large cuts do not provide optimal moose habitat due to increased homogeneity and the reduction of critical thermal and escape cover (see Appendix 3 for references). Moose will not make use of available forage in large open areas which do not contain residual stands of mature forest cover, and generally will not move more than about 80 to 200 m from cover, particularly during periods of deep snow (Eastman 1974, Hamilton et al. 1980, Tomm \& Beck 1981, Allen et al. 1987, Peek et al. 1987, Jackson et al. 1991, Thompson et al. 1995). Studies have demonstrated that moose will not begin to preferentially use cutovers until 10 to 15 years post-cut, when some degree of forest cover has returned, even if forage is available in the cuts prior to this period (Monthey 1984, Potvin et al. 1999).

Silvicultural practices which favour establishment of single-species coniferous stands do not produce desirable food species for moose, and often include the use of herbicides (Prescott 1968, Peek et al. 1976, Joyal 1987). Glyphosate is commonly used on clearcuts in Nova Scotia to discourage deciduous growth in favour of merchantable conifer species which do not provide high quality moose forage (Escholz et al. 1996, Raymond et al. 1996). Studies have produced conflicting results regarding the effects of glyphosate on moose habitat (Connor \& McMillan 1990, Escholz et al. 1996, Raymond et al. 1996, Hjeljord 1994, Santillo 1994), and the effects of glyphosate ingestion on the health of wildlife are unclear, although Raymond et al. (1996) suggested that toxic effects are minimal.

Large-scale harvesting that leaves few stands of mature forest and cultivation of even-aged, single-species stands reduce and fragment moose habitat and result in forest homogeneity. Timber harvest by selective or partial cutting can enhance moose habitat by producing an interspersion of food producing areas within an adequate supply of shelter (Prescott 1968, Telfer 1984, Cederlund \& Sand 1992, Pulsifer 1995). In general, 
forest management for moose habitat should maintain at least 55 to $70 \%$ mature cover-providing forest distributed in patches no smaller than about 8 ha, and should retain some large patches of residual cover (up to $100 \mathrm{ha}$ ) with disturbances designed so there is never more than $200 \mathrm{~m}$ to cover from any point (see Appendix 3 for references).

\section{Land Development}

Human settlement and development, land clearing, cultivation, urbanization, and recreational development restrict and eliminate moose habitat (Houston 1968, Dodds 1974). Roads, trails, and other utility corridors provide access for competitors and predators, increase hunting pressure, fragment and convert habitat, disturb wildlife during construction and use, and increase mortality by vehicle collision (Houston 1968, Prescott 1968, Peek et al. 1987, Hogg 1990, Forman et al. 1997, Jalkotzy et al. 1997, Rempel et al. 1997). Although roads may provide open forage-producing areas, moose frequently do not take advantage of the increased forage availability, and any benefits are offset by associated disturbances and increasing mortality rates (Timmermann \& Gollath 1982, Forman et al. 1997, Jalkotzy et al. 1997). Analysis of pellet group data indicated that moose in mainland Nova Scotia preferentially select areas with few or no roads, and less frequently occupy areas of high road density (Snaith 2001, Beazley et al. 2004). Thus, the retention of areas of low road density, such as in the Tobeatic area, and the decommissioning of forestry harvesting roads after use may be critical to the maintenance of moose populations in Nova Scotia.

\section{Moose Ranging Behaviour and Area Requirements}

Globally, moose show considerable variation in their ranging patterns and home range size (Appendix 4). This variation is likely due to the variability among sites in climate, range quality, and the degree of interspersion of essential habitat components. Annual home range sizes reportedly vary from $12.6 \mathrm{~km}^{2}$ in Sweden where the habitat is of excellent quality with small-scale disturbances, a mixture of successional stages, and high resource availability (Cederlund \& Okarma 1988), to $200-500 \mathrm{~km}^{2}$ in Alaska and the Northwest Territories where moose are forced to travel much further to meet their daily and seasonal requirements (Taylor \& Ballard 1979, Ballard et al. 1991, Stenhouse 1995). Population density tends to be greater in areas with good habitat quality where individuals occupy smaller home ranges (Sweanor \& Sandegren 1989).

There are few estimates of home range size and range use patterns for moose in Nova Scotia. Preliminary results of an ongoing study indicate that moose in the southwestern population occupy a mean annual home range of $55.2 \mathrm{~km}^{2}$ with overlapping seasonal ranges $\left(n=8 ; r=13.29-129.84 \mathrm{~km}^{2}\right.$; based on two years of observation and 51 to 63 relocations/individual) (calculation based on figures from Brannen (2000)). There are no estimates for home range size of individuals in the more mountainous habitat of the Cobequids. However, data from similar habitat areas in Maine and the Gaspé Peninsula suggest that widely separated seasonal ranges are not necessary, and that home ranges vary from $20 \mathrm{~km}^{2}$ to $50 \mathrm{~km}^{2}$ (Dunn 1976, Crossley \& Gilbert 1983, Crete 1989, Leptich \& Gilbert 1989, Thompson et al. 1995) (Appendix 4). Because moose are known to adapt to widely distributed resources by ranging over large areas (Lynch \& Morgantini 1984), it is possible that the reported area requirements in the southwest region of Nova Scotia are slightly larger than estimates from Maine and the Gaspé Peninsula because resources are more sparse in the rocky barrens characteristic of southwest Nova Scotia. 
Nova Scotia moose do not exhibit long-distance seasonal migrations; however, local seasonal movements do occur in response to food availability and snow conditions, especially in the mountainous Cobequid region (NSDLF undated, Benson 1957). Winter home ranges are much smaller than summer ranges because movement is restricted due to lower food availability and the constraints of travel associated with snow accumulation (Telfer 1967a, b). Moose winter ranging behaviour in the Cobequids is characterized by localized concentrations of moose in yards which are small, intensively used areas within a restricted winter range of $2.6 \mathrm{~km}^{2}$ (Telfer $1967 \mathrm{a}, \mathrm{b}$ ). Summer range requirements are much larger due to increased travel associated with feeding activities. Based on the literature cited above, and the ongoing study in the Tobeatic, 20 to $50 \mathrm{~km}^{2}$ of good habitat is likely a conservative estimate of the area required by an individual moose.

\section{Population Density}

Worldwide, there is generally a great range of variation in moose population density (Appendix 4), and it is difficult to determine the ideal density and structure of a healthy population. Although current average densities are not known, mainland moose populations are at much lower densities than they have been in the past (NSDLF undated, Benson 1957, Dodds 1963, 1974, Telfer 1968b, Prescott 1968, Pulsifer 1995, Pulsifer \& Nette 1995, Timmermann \& Buss 1997). Traditionally, the highlands of the northeastern mainland have maintained the greatest moose densities, and likely still do, although some evidence indicates that there are a few local concentration areas with relatively high densities in the Tobeatic (Benson 1958, Dodds 1963, Prescott 1968, Nette 2000). Currently, population density in the Cobequid Highlands is estimated to be 0.01 to 0.09 moose $/ \mathrm{km}^{2}$, while in the southwest, population density is approximately 0.05 moose $/ \mathrm{km}^{2}$ or less, with local concentrations of up to 0.35 moose $/ \mathrm{km}^{2}$ (Pulsifer \& Nette 1995, Nette 2000).

Moose populations elsewhere exist at similarly low densities, and are likely maintained at low levels due to poor range conditions, restricted sodium availability, reduction of winter habitat due to forest management, hunting mortality, and predation pressure (for example, Former Soviet Union: Filonov \& Zykov 1974, Kistchinski 1974, Syroechkovskiy \& Rogacheva 1974; Newfoundland: Albright \& Keith 1987; Labrador: Chubbs \& Schaefer 1997; Northwest Territories: Stenhouse 1995; Quebec: Brassard et al. 1974, Joyal \& Sherrer 1978, Crete \& Courtois 1997; Ontario: Thompson \& Euler 1987, Duinker et al. 1996; Alberta: Hauge \& Keith 1981; Alaska: MacCracken et al. 1997). These factors, among others as described below, may be acting to limit or regulate Nova Scotia moose populations, and must be carefully considered when assessing population viability or designing conservation and management plans for moose habitat.

\section{Regulating Factors}

\section{Habitat Suitability and Degradation}

In some areas, moose show density-dependent population regulation based on resource availability. Reproductive rates and survival are linked to nutritional status, and poor range conditions lead to lower body weight, slower development, delayed sexual maturity, lower calf production, and increased mortality (NSDLF undated, Messier \& Crete 1984, Franzman \& Schwartz 1986, Fowler 1987, Karns 1987, Page 
1987, Andersen 1991, Wallin et al. 1995, Sand et al. 1996, Crete \& Courtois 1997, Saether 1997, Hjeljord \& Histol 1999). Some studies suggest that winter food availability is an important limiting factor affecting mortality rates, population density, and carrying capacity (Stevens 1970, Peek 1974b, Crete \& Jordan 1982, Albright \& Keith 1987, Cederlund \& Markgren 1987, Crete 1989, Andersen 1991, Ballard et al. 1991). However, a number of reports suggest that food availability is not likely a limiting factor for moose, even during winter (Crete \& Jordan 1982, Messier \& Crete 1984, Miquelle et al. 1992, Joyal 1987, Bontaites \& Gustafson 1993, Saether et al. 1996). Hjeljord \& Histol (1999) suggest that density-dependent resource limitation is unlikely to occur until moose reach very high densities. The quality of food resources or the presence of other critical habitat components, such as adequate cover, may be more important factors affecting moose population densities and distribution (Oldemeyer 1974, Peek 1974b, Regelin et al. 1987, Miquelle et al. 1992, Puttock et al. 1996).

Population stability is also affected by fluctuations in habitat characteristics due to disturbances such as blow-downs, fires, forest management and insect infestations, which influence forage production (Telfer 1984, Bobek \& Morow 1987, Cederlund \& Sand 1991, Bontaites \& Gustafson 1993). Habitat disturbance at a large scale may restrict or significantly fragment moose habitat, particularly thermal cover, which may lead to decreasing moose populations while at the same time favouring the expansion of deer, a possible competitor (Telfer 1970b, Dodds 1974, Bontaites \& Gustafson 1993, Pulsifer 1995). Forest conversion for agriculture, industry, and urbanization have led to the reduction and extirpation of moose in portions of Europe, the United States, Nova Scotia, Ontario, and Quebec (Dodds 1974, Telfer 1984). Continuing forest conversion, degradation and fragmentation in Nova Scotia, including through forest harvesting, may decrease habitat suitability and availability, and further increase pressure on moose populations.

\section{Climate}

Seasonal climatic fluctuations affect moose health, and in extreme cases may limit populations directly by increasing mortality, or indirectly by affecting food availability. Severe winter weather, and heat stress during hot summers, may cause decreased forage intake and increased energy expenditures for thermoregulation which in turn might decrease fat storage and ultimately increase winter mortality (Renecker \& Hudson 1986, Ackerman 1987). Because Nova Scotia is near the southern limit of moose range, heat stress likely occurs during both late winter and hot summer months. Summer and winter thermal stress, if combined with a lack of adequate mature forest for thermal protection and few aquatic resources, may be an important factor affecting moose populations in the province.

The current global warming trend has the potential to greatly affect moose populations in Nova Scotia, which are already close to the limit of heat tolerance. A period of rapid human-induced atmospheric and climate change will lead to changes in range conditions and may decrease habitat quality (Peters \& Darling 1985, Graham 1988, Hunter et al. 1988, Davis \& Zabinski 1992, Dawson 1992, Lovejoy 1992, Murphy \& Weiss 1992, Peters 1992, Shugart \& Smith 1992). The effects of these changes will be compounded by an increasingly developed landscape where there are physical barriers to animal movement and few remaining connected natural areas for dispersal.

\section{Moose Interactions with White-Tailed Deer}

Northward expansion of white-tailed deer (Odocoileus virgianus) populations into areas traditionally occupied by moose has been associated with increasing human-induced environmental change. White-tailed deer are highly adaptable and prefer 
deciduous forest habitat and forest edges associated with open areas (Anderson 1972). Over the past 150 to 200 years, agricultural and linear corridor development and forest management practices throughout Nova Scotia have opened up the forests, creating browse and cover conditions suitable for deer (Anderson 1965, 1972, Karns 1967, Prescott 1974, Lankester 1987). White-tailed deer appeared in Nova Scotia in the late nineteenth century and became the dominant cervid by the mid-twentieth century, while moose numbers dwindled (Benson 1958, Telfer 1967b, Anderson 1972, Pulsifer 1995). Similar trends have been reported for New Brunswick (Telfer 1968a), Maine (Gilbert 1973, 1974), Ontario (Anderson 1965, Saunders 1973) and Minnesota (Karns 1967). These declines in moose numbers have often been attributed to a sickness caused by the parasitic nematode, Paralephostrongylus tenuis, normally associated with white-tailed deer. However, the initial habitat alterations themselves, or the increased interspecific food competition subsequent to the increase in deer density may also have been significant factors in the reduction of moose numbers (Wright 1956, Benson 1957, Telfer 1970b, 1984, Banfield 1974, Prescott 1974, Strandgaard 1982, Telfer \& Cairns 1986, Karns 1987, Pulsifer 1995).

Direct food competition may be unlikely because moose and white-tailed deer are frequently separated by differential habitat selection (Telfer 1967b, 1968a, 1970a, Gilbert 1974, Telfer \& Cairns 1986, Kearney \& Gilbert 1976). In many cases, spatial separation occurs during the winter months. Because deer are less tolerant of snow, they are forced to move to lower altitudes or into more dense conifer cover than is required by moose (Telfer 1968a, Tierson et al. 1985). However, forest conversion associated with the creation of roads and open areas, as well as climate warming trends, may continue to favour deer populations over moose.

\section{Disease}

Moose populations in Nova Scotia may be significantly affected by a number of diseases including brainworm (P.tenuis), winter ticks (Dermacentor albipictus), and nutritional deficiencies or toxicity due to environmental contamination. $P$. tenuis is a common parasite of white-tailed deer in eastern North America, and can be transmitted to moose via terrestrial gastropods (snails), the intermediate host (Anderson 1963, 1972). White-tailed deer can tolerate the parasite without any pathogenic symptoms. However, $P$. tenuis is highly pathogenic and often fatal to moose (Telfer 1970a, Anderson 1972, Gilbert 1973, 1974). In moose, the worms may cause severe trauma to the central nervous system, neurological disease, paralysis, and death, and may predispose moose to mortality by other causes such as hunting and accidental death due to abnormal behaviour (Benson 1958, Anderson 1964, Gilbert 1974, Thomas \& Dodds 1988).

For many years, $P$. tenuis was commonly accepted as a major factor in moose population declines that seemed to be associated with increasing deer densities (Anderson 1964, 1965, 1972, Karns 1967, Telfer 1967b, 1970a, 1984, Gilbert 1973, 1974, Saunders 1973, Dodds 1974, Prescott 1974, Peek et al. 1976, Clarke \& Bowyer 1986, Geist 1987, Lankester 1987, Thomas \& Dodds 1988, Pulsifer 1995). More recent evidence suggests, however, that it may only be a marginal limiting factor (Telfer 1967b, 1968a, 1970a, Gilbert 1973, 1974, Kearney \& Gilbert 1976, Saunders 1973, Anderson 1972, Nudds 1990, Whitlaw \& Lankester 1994, Dumont \& Crete 1996, Lankester \& Peterson 1996). While P. tenuis may not be the principal cause of mortality and declining moose populations in Nova Scotia, it is likely a contributing factor that should be assessed along with food competition, habitat alteration, and other causes of mortality. 
The winter tick is a common parasite in Nova Scotia and, due to very large tick loads observed on moose in the province, may also be a significant mortality factor for moose

(NSDLF undated, Nette 2000). Ticks remove nutrients and blood and introduce pharmacological agents to the bloodstream which trigger increased grooming and thus premature shedding of the winter coat (Hodgdon 1961, Samuel et al. 1986, Samuel 1991). Loss of hair during the winter months can lead to thermal stress, increased metabolic demands, and hypothermia (Samuel 1991). These effects have been linked to winter nutritional stress, increased mortality, and declining moose populations in Michigan and Alberta (DelGiudice et al. 1997). Increased tick infestations seem to be associated with relatively short and mild winters; mild autumn weather allows a longer infestation period, and early spring melt produces favourable conditions for the reproduction and survival of ticks (Telfer 1984). Telfer (1984) observed these conditions in southern Alberta where a heavy tick load has been associated with increased mortality and may be limiting moose populations and distribution. Similar conditions may exist in other areas at the southern limit of moose range such as Nova Scotia.

Environmental contaminants and nutritional deficiencies have also been linked to moose disease/mortality and population declines. Elevated levels of heavy metals and trace metal imbalances due to environmental contamination may be contributing to moose mortalities in Nova Scotia (Nette 2000). Industrial pollution causes soil acidification and increased cadmium availability (Scanlon et al. 1986, Outridge et al. 1994, Selenius et al. 1996, Frank \& Galgan 1997, Selenius \& Frank 2000, Freedman 2001). At high levels, cadmium may have toxic effects on the central nervous and reproductive systems of moose (Scanlon et al. 1986). Outridge et al. (1994) determined that mammals are at risk when kidney cadmium concentrations exceed $30 \mathrm{mg} /$ kg. Moose kidneys collected in Nova Scotia between 1998 and 2000 have shown cadmium concentrations as high as $148 \mathrm{mg} / \mathrm{kg}$ (wet weight, 7 year old animal), well beyond the level considered to be safe, and much higher than levels recorded in neighbouring jurisdictions (Nette 2000). Elevated cadmium levels may be a factor contributing to high rates of moose calf mortality in the southwestern region of the province (Nette 2000).

In areas with little buffering capability, soil acidification is associated with decreasing copper availability due to leaching (Frank et al. 1994, Frank \& Galgan 1997). This may result in copper deficiency among moose, causing symptoms similar to those of $P$. tenuis including atrophy, neurological disease, impaired vision, emaciation, motor disturbances, circling, convulsions, and death (Frank et al. 1994, Selenius et al. 1996, Frank 1998). Interestingly, an increase in $\mathrm{pH}$, as occurs with liming treatment to counter the effects of acidification, may also decrease the availability of copper in soil and cause copper deficiency, the effects of which are compounded by an increase in environmental molybdenum, which also results from liming (Frank et al. 1994, Frank \& Galgan 1997, Frank 1998). Further investigation is required to provide conclusive evidence regarding moose mortality due to cadmium toxicity or copper deficiency in Nova Scotia (Nette 2000).

\section{Hunting and Predation}

Hunting pressure has been the cause of major moose declines in Nova Scotia and elsewhere (Dodds 1974, Bontaites \& Gustafson 1993), and has been responsible for maintaining low population densities or for extirpation in some portions of traditional moose range (Telfer 1984, Wolfe 1987, Duinker et al. 1996). Due to declining populations, the hunting season was closed in 1937 in the western and central portions of mainland Nova Scotia, while some eastern counties periodically opened the hunt until 1981 (Dodds 1963, Nette 2000). Although there is currently no legal harvest of 
moose on the mainland, with the exception of that by First Nations, there is evidence to suggest that a few animals are illegally taken on a yearly basis, especially in the Cobequid Hills where more roads provide easier access (Nette 2000). Thus, it remains possible that poaching is among the factors affecting moose populations (Dodds 1963, Wolfe 1987, Pulsifer 1995, Chubbs \& Schaeffer 1997, Nette 2000).

Although wild predators are rarely responsible for local extirpation of prey species (because to do so would be maladaptive), heavy predation in combination with other factors such as disease, severe winters, and marginal range may limit populations and perhaps cause declines and extirpation (Telfer 1984). It has often been assumed that due to the absence of wolves, predation has had little effect on moose populations in Nova Scotia (NSDLF undated, Benson 1957, Dodds 1974). However, it has been recently recognized that black bear predation can be a significant calf mortality factor, and can potentially restrict populations in areas of low population density (Wright 1956, Messier \& Crete 1984, Franzmann \& Schwartz 1986, Fowler 1987, Karns 1987, Larsen et al. 1989, McNicol 1990, van Ballenberghe \& Ballard 1994, Bontaites \& Gustafson 1993, Pulsifer 1995, Stenhouse 1995, Chubbs \& Schaeffer 1997). Low-density moose populations are sympatric with stable black bear populations throughout their range in Nova Scotia (Nette 2000); thus, black bear predation of calves may be a potentially significant limiting factor.

\section{Population Viability}

Natural populations are subject to stochastic and deterministic factors which influence birth and death rates and lead to fluctuations in population size. Small, isolated populations are especially vulnerable to extinction in the face of demographic, genetic and environmental changes (Diamond 1976, Terborgh \& Winter 1980, Shaffer 1981, Newmark 1985, Samson et al. 1985, Gilpin \& Soulé 1986, Gilpin 1991, Henriksen 1997). Population viability assessment (PVA) has become a popular tool in wildlife conservation, and is used to determine the minimum viable population size (MVP) (Shaffer 1990, Boyce 1992, Theberge 1993, Lacy 1993/94, Reed et al. 1986, 1998). MVP represents the population size below which the probability of extinction is unacceptably high, but at or above which the probability of extinction is reduced to an acceptable level over a given time period (Samson 1983, Gilpin \& Soulé 1986, Lacy 1993/94, Henriksen 1997). To obtain a useful and reliable prediction of MVP through PVA, detailed information is required on species demography, ecology, genetics, and habitat relationships, as well as local environmental conditions and variability. In many cases, these data are not available; however, some general rules have been developed based primarily on genetic considerations and are supported by empirical and experimental evidence (Franklin 1980, Soulé 1980, Shaffer 1981, 1983, Brussard 1985, Samson et al. 1985, Lande 1987, Berger 1990, Thomas 1990, Henricksen 1997). For short-term viability (a few decades), a minimum effective population of 50 individuals is required to avoid inbreeding depression; however, to avoid the longterm (centuries) loss of genetic variability through drift, a population should include at least 500, or even 5000, individuals. Furthermore, these estimates only refer to the genetically effective population $\left(\mathrm{N}_{\mathrm{e}}\right)$ which represents the number of randomly breeding individuals, and is often much lower than the actual census population $(\mathrm{N})$ (Franklin 1980, Brussard 1985, Newmark 1985, Samson et al. 1985, Henriksen 1997).

Preliminary MVP figures have been calculated for moose in mainland Nova Scotia (Beazley 1998, Snaith 2001). Because the information required for a reliable PVA is unavailable, these figures are estimates based on the general assumption that 500 breeding individuals are enough to ensure long-term viability (Franklin 1980). A tento-one relationship between $\mathrm{N}$ and $\mathrm{N}_{\mathrm{e}}$ was applied based on calculations made for 
moose elsewhere (Ryman et al. 1981, Arsenault 2000). Using this $10 \%$ relationship, it follows that for an effective population size of 500 moose, an actual minimum viable census population of 5000 individuals is required to ensure long-term persistence. The current population of 1000 moose, fragmented among a number of smaller and isolated populations, is not enough to ensure the persistence of moose over the long term (Snaith 2001, Snaith \& Beazley 2003).

In order to address conservation problems, MVP requires spatial application; in other words, the amount of habitat required to support the MVP must be calculated. The minimum critical area (MCA) represents the minimum amount of suitable habitat required to support the population, and is calculated based on the number of individuals and their area requirements or population density (Soulé 1980, Shaffer 1981, Lehmkhul 1984, Newmark 1985, Metzgar \& Bader 1992, Theberge 1993, Doncaster et al. 1996, Arsenault 2000).

For moose in Nova Scotia, MCA can be calculated using the MVP size, multiplied by the area requirements (home range size) of each individual or by dividing MVP by the average regional population density (Shaffer 1981, Newmark 1985, Theberge 1993, Doncaster et al. 1996, Beazley 1997, 1998, Snaith 2001). Based on local average home range sizes (30-55 $\left.\mathrm{km}^{2}\right)$ and density $\left(0.05 / \mathrm{km}^{2}\right)$, MCA for long term viability was

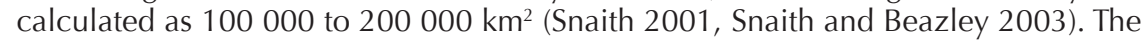
total area of mainland Nova Scotia is about $45000 \mathrm{~km}^{2}$. Clearly, if these calculations are correct, Nova Scotia is not large enough on its own to maintain a viable moose population over the long term. Connectivity among local moose populations and to those in New Brunswick is essential for the maintenance of moose in Nova Scotia.

\section{Conclusion}

Mainland Nova Scotia moose populations have been considerably reduced from pre-Euro-American contact levels and may currently be declining due to a number of factors including habitat conversion, degradation, and fragmentation, interspecific competition, disease, environmental contamination, predation, and poaching. Although the causes of the decline of moose in Nova Scotia remain ambiguous, it is clear that the population has dropped to levels low enough to place them at risk. Because Nova Scotia moose populations are small and isolated, they are particularly susceptible to further reductions through genetic, demographic, or environmental fluctuations.

Currently, the Nova Scotia mainland does not support a moose population large enough to persist for the long term, nor does it contain enough area to support such a population in isolation. In order to ensure the persistence of moose in Nova Scotia, conservation efforts should concentrate on the following:

i. maintaining and enhancing all seasonally critical habitat elements (including forage, thermal and escape cover, calving areas, winter yards, and water bodies) in and around areas where moose currently exist;

ii. designing forestry management strategies to maintain and enhance sufficient thermal cover and interspersion of habitat elements;

iii. increasing understanding, through empirical research, of potential population limiting/regulating factors;

$i v$. reestablishing habitat connectivity for dispersal/migration between the two mainland populations to allow genetic exchange which will increase the effective population size; 
v. restoring the critical habitat area and components required to support an increase in the population to long-term MVP level: habitat restoration should aim to improve the quantity of habitat (to support more individuals on a larger area) and the quality of habitat (to support a larger population on the same area at higher densities); and,

vi. reestablishing habitat connectivity with New Brunswick to allow dispersal and migration to increase gene flow and to further increase effective population size over the long term; this will also allow opportunities for responses to climate change.

In light of the information presented in the literature, as well as what is known about moose in mainland Nova Scotia, further attention to their distibution, status and habitat associations is warranted.

\section{References}

Ackerman TN (1987) Moose response to summer heat. MSc thesis, Michigan Technological University, Houghton, MI

Albright CA, Keith LB (1987) Population dynamics of moose, Alces alces, on the south-coast barrens of Newfoundland. Can Field-Nat 101:373-387

Allen AW, Jordan PA, Terrell JW (1987) Habitat suitability index models: moose, Lake Superior region. US Dep Inter Biol Rep 82:1-47

Andersen R (1991) Habitat deterioration and the migratory behaviour of moose (A/ces alces L) in Norway. J Appl Ecol 28:102-108

Anderson RC (1963) The incidence, development, and experimental transmission of Pneumostrogylus tenuis dougherty (Metastrongyloidea: Protostrongylidae) of the meninges of the white-tailed deer (Odocoileus virginianus borealis) in Ontario. Can J Zool 41:775-792

Anderson RC (1964) Neurologic disease in moose infected experimentally with Pneumostrongylus tenuis from white-tailed deer. Pathol Vet 1:289-322

Anderson RC (1965) An examination of wild moose exhibiting nuerologic signs in Ontario. Can J Zool 43:635-639

Anderson RC (1972) The ecological relationships of meningeal worm and native cervids in North America. J Wildl Dis 8:304-310

Arsenault AA (2000) Status and management of moose (Alces alces) in Saskatchewan. Fish Wildl Tech Rep 00-1:1-84

Ballard WB, Whitman JS, Reed DJ (1991) Population dynamics of moose in southcentral Alaska. Wildl Monogr 114:1-49

Banfield AWF (1974) Mammals of Canada. University of Toronto Press, Toronto

Basquille S, Thompson R (1997) Moose (A/ces alces) browse availability and utilization in Cape Breton Highlands National Park. Parks Canada Tech Rep in Ecosyst Sci 10:1-37

Belovsky GE (1981) Food plant selection by a generalist herbivore: the moose. Ecol (Tempe) 62:1020-1030

Beazley KF (1997) Ecological considerations for protected area system design. Proc NS Inst Sci 41:59-76

Beazley KF (1998) A focal-species approach to biodiversity management in Nova Scotia. PhD thesis, Dalhousie University, Halifax

Beazley K, Snaith T, Colville D, MacKinnon F, Brown S (2004) Road density and impacts on mammals in Nova Scotia. Proc NS Inst Sci, 42:339-357 
Benson DA (1957) The moose in Nova Scotia. NS Dep Lands For Bull 17:1-12

Benson DA (1958) Moose "sickness" in Nova Scotia. Can J Comp MedVet Sci 22:244-248

Berg WE, Phillips RL (1974) Habitat use by moose in northwestern Minnesota with reference to other heavily willowed areas. Nat Can (Que) 101:101-116

Berger J (1990) Persistence of different-sized populations: an empirical assessment of rapid extinctions in bighorn sheep. Conserv Biol 4:91-98

Bobek B, Morow K (1987) Present status of moose in Poland. Swed Wildl Res Viltrevy Suppl 1:69-70

Bontaites KM, Gustafson K (1993) The history and status of moose and moose management in New Hampshire. N Am Moose Conf Worksh 29:163-167

Bowyer RT, van Ballenberghe V, Kie JG, Maier JAK (1999) Birth-site selection by Alaskan moose: maternal strategies for coping with a risky environment. J Mammal 80:1070-1083

Boyce MS (1992) Population viability analysis. Annu Rev Ecol Syst 23:481-506

Brannen D (2000) (Nova Scotia Department of Natural Resources (NSDNR), Wolfville, NS). Personal communication

Brassard JM, Audy E, Crete M, Grenier P (1974) Distribution and winter habitat of moose in Quebec. Nat Can (Que) 101:67-80

Brussard PF (1985) Minimum viable populations: how many are too few? Rest Manag Notes 3:21-25

Cederlund G, Markgren G (1987) The development of the Swedish moose population, 1970-1983. Swed Wildl Res Viltrevy Suppl 1:55-62

Cederlund G, Okarma H (1988) Home range and habitat use of adult female moose. J Wildl Manag 52:336-343

Cederlund G, S and H (1991) Population dynamics and yield of a moose population without predators. N Am Moose Conf Worksh 27:31-40

Cederlund G, Sand H (1992) Dispersal of subadult moose (Alces alces) in a nonmigratory population. Can J Zool 70:1309-1314

Cederlund G, Sand H (1994) Home-range size in relation to age and sex in moose. J Mammal 75:1005-1012

Cederlund G, Sandegren F, Larsson K (1987) Summer movements of female moose and dispersal of their offspring. J Wildl Manag 51:342-352

CESCC (Canadian Endangered Species Council) (2001) Wild Species 2000: the general status of species in Canada. Department of Public Works and Government Services, Ottawa

Chubbs TE, Schaeffer JA (1997) Population growth of moose, Alces alces, in Labrador. Can Field-Nat 111:238-242

Clarke RA, Bowyer RT (1986) Occurrence of protostrongylid nematodes in sympatric populations of moose and white-tailed deer in Maine. N Am Moose Conf Worksh 22:313-322

Coady JW (1974) Influence of snow on behavior of moose. Nat Can (Que) 101:417-436

Collins WB, Helm DJ (1997) Moose, Alces alces, habitat relative to riparian succession in the boreal forest, Susitna River, Alaska. Can Field-Nat 111:567-574

Connor JF, McMillan LM (1990) Water utilization by moose of glyphosate-treated cutovers. Northwest Ontario Forest Technology Development Unit Tech Rep 56, Ontario Department of Natural Resources, Thunder Bay, ON

COSEWIC (Committee on the Status of Endangered Wildlife in Canada) (2000) Canadian species at risk. COSEWIC, Canadian Wildlife Service, Environment Canada, Ottawa 
Crawford HS (1993) Effects of forest disturbance and soil depth on digestible energy for moose and white-tailed deer. United States Department of Agriculture, Radnor, PA

Crete M (1987) The impact of sport hunting on North American moose. Swed Wildl Res Viltrevy Suppl 1:553-563

Crete M (1989) Approximation of $K$ carrying capacity for moose in eastern Quebec. Can J Zool 67:373-380

Crete M, Courtois R (1997) Limiting factors might obscure population regulation of moose (Cervidae: Alces alces) in unproductive boreal forests. J Zool (London) 242:765-781

Crete M, Jordan PA (1982) Population consequences of winter forage resources for moose, Alces alces, in southwestern Quebec. Can Field-Nat 96:467-475

Crossley A, Gilbert JR (1983) Home range and habitat use of female moose in northern Maine: a preliminary look. Trans Northeast Sec Wildl Soc 40:67-75

Davis MB, Zabinski C (1992) Changes in geographical range resulting from greenhouse warming. In: Peters RL, Lovejoy TE (eds) Global warming and biological diversity. Yale University Press, New Haven, CT, p 297-308

Dawson WR (1992) Physiological responses of animals to higher temperatures. In: Peters RL, Lovejoy TE (eds) Global warming and biological diversity. Yale University Press, New Haven, CT, p 158-170

de Vos A (1958) Summer observations on moose behaviour in Ontario. J Mammal 39:128-139

DelGiudice GD, Peterson RO, Samuel WL (1997) Trends of winter nutritional restriction, ticks and numbers of moose on Isle Royale. J Wildl Manag 61:895-903

Demarchi MW, Bunnell FL (1995) Forest cover selection and activity of cow moose in summer. Acta Theriol 40:23-36

Des Meules P (1964) The influence of snow on the behaviour of moose. Travaux En Cours 3:51-73

Diamond JM (1976) Island biogeography and conservation: strategy and limitations. Science (Wash DC) 193:1027-1029

Dodds DG (1963) The present status of moose (Alces alces americana) in Nova Scotia. Trans Northeast Fish Wildl Conf 2:1-40

Dodds DG (1974) Distribution, habitat and status of moose in the Atlantic provinces of Canada and northeastern United States. Nat Can (Que) 101:51-65

Doerr JG (1983) Home range size, movements and habitat use in two moose, Alces alces, populations in southeastern Alaska. Can Field-Nat 97:79-88

Doncaster CP, Micol T, Jenson SP (1996) Determining minimum habitat requirements in theory and practice. Oikos 75:335-339

Duinker P, Daniel C, Morash R, Stafford W, Plinte R, Wedeles C (1996) Integrated modelling of moose habitat and population: preliminary investigations using an Ontario boreal forest. Lakehead University, Thunder Bay, ON

Dumont A, Crete M (1996) The meningeal worm, Parelaphostrongylus tenuis, a marginal limiting factor for moose, Alces alces, in southern Quebec. Can Field-Nat 110:413-418

Dunn F (1976) Behavioural study of moose. Maine Department of Inland Fish and Wildlife Project, W-66-R-6 Job 2-1

Eastman DS (1974) Habitat use by moose of burns, cutovers and forests in north-central British Columbia. Proc N Am Moose Conf Worksh 10:238-256

Eastman DS, Ritcey R (1987) Moose habitat relationships and management in British Columbia. Swed Wildl Res Viltrevy Suppl 1:101-117 
Ecological Stratification Working Group (1995) A national ecological framework for Canada. Agri-Food Canada, Environment Canada, Ottawa/Hull

Eschholz WE, Servello FA, Griffith B, Raymond KS, Krohn WB (1996) Winter use of glyphosate-treated clearcuts by moose in Maine. J Wildl Manag 60:764-769

Filonov CP, Zykov CD (1974) Dynamics of moose populations in the forest zone of the European part of the USSR and the Urals. Nat Can (Que) 101:605-613

Forbes GJ, Theberge JB (1993) Multiple landscape scales and winter distribution of moose, Alces alces, in a forest ecotone. Can Field-Nat 107:201-207

Forman RTT, Friedman DS, Fitzhenry D, Martin JD, Chen AS, Alexander LE (1997) Ecological effects of roads: toward three summary indices and an overview for North America. In: Canters K (ed) Habitat fragmentation and infrastructure. Ministry of Transport, Public Works and Government Services, Delft, Netherlands, p 40-54

Fowler CW (1987) A review of density dependence in populations of large mammals. Curr Mammal 1:401-441

FrankA (1998) 'Mysterious' moose disease in Sweden: similarities to copper deficiency and/or molybdenosis in cattle and sheep: biochemical background of clinical signs and organ lesions. Sci Total Environ 209:17-26

Frank A, Galgan V (1997) The moose (Alces alces I.), a fast and sensitive monitor of environmental changes. In: Subramanian KS, Iyengar GV (eds) Environmental biomonitoring: exposure assessment and specimen banking. American Chemical Society, Washington, DC, p 57-64

Frank A, Galgan V, Petersson LR (1994) Secondary copper deficiency, chromium deficiency and trace element imbalance in the Moose (Alces alces I.): effect of anthropogenic activity. Ambio 23:315-317

Franklin IR (1980) Evolutionary change in small populations. In: Soulé ME, Wilcox ME (eds) Conservation biology: an evolutionary ecological perspective. Sinauer Associates, Sunderland, MA, p 135-150

Franzmann AW, Schwartz CC (1986) Black bear predation on moose calves in highly productive vs. marginal moose habitats on the Kenai Peninsula, Alaska. NAm Moose Conf Worksh 22:139-154

Freedman B (2001) Environmental science: a Canadian perspective. Prentice Hall, Toronto

Geist V (1987) On the evolution and adaptations of Alces. Swed Wildl Res Viltrevy Suppl 1:11-23

Gilbert FF (1973) Paralephostrongylus tenuis (Dougherty) in Maine: I - the parasite in white-tailed deer (Odocoileus virginianus, Zimmerman). J Wildl Dis 9:136-143

Gilbert FF (1974) Parelaphostrongylus tenuis in Maine: II - prevalence in moose. J Wildl Manag 38:42-46

Gilpin M (1991) The genetic effective size of a metapopulation. Biol J Linn Soc 42:165-175

Gilpin M, Soulé ME (1986) "Minimum viable populations: processes of species extinction". In: Soulé ME (ed) Conservation biology: the science of scarcity and diversity. Sinauer Associates, Sunderland, MA, p 19-34

Graham RW (1988) The role of climate change in the design of biological reserves: the paleoecological perspective for conservation biology. Conserv Biol 2:391-394

Hall R (2000) (Nova Scotia Department of Natural Resources (NSDNR), Wolfville, NS). Personal communication

Hamilton GD, Drysdale PD, Euler DL (1980) Moose winter browsing patterns on clear-cuttings in northern Ontario. Can J Zool 58:1412-1416

Hauge TM, Keith LB (1981) Dynamics of moose populations in northeastern Alberta. J Wildl Manag 45:573-597 
Heikkila R, Nygran K, Harkonen S, Mykkanen A (1996) Characteristics of habitats used by female moose in the managed forest area. Acta Theriol 41:321-326

Henriksen G (1997) A scientific examination and critique of minimum viable population size. Fauna Nor 18:33-41

Histol T, Hjeljord O (1993) Winter feeding strategies of migrating and nonmigrating moose. Can J Zool 71:1421-1428

Hjeljord O (1994) Moose (Alces alces) and mountain hare (Lepus timidus) use of conifer plantations following glyphosate application. Norw J Agric Sci 8:181-188

Hjeljord O, Histol T (1999) Range-body mass interactions of a northern ungulate - a test of hypothesis. Oecologia 119:326-339

Hjeljord O, Hovik N, Pedersen H (1990) Choice of feeding sites by moose during summer, the influence of forest structure and plant phenology. Holarct Ecol 13:281-292

Hodgdon KW (1961) His majesty the moose. Maine Fish and Game, Spring 1961:4-25

Hogg D (1990) Moose management: the forest habitat. In: Ontario Department of Natural Resources (ed) The moose in Ontario, Book 1- Moose biology, ecology and management. Queen's Printer for Ontario, Toronto, p 30-33

Houston DB (1968) The Shiras moose in Jackson Hole, Wyoming. United States Department of the Interior Tech Bull 1:1-62

Hunter ML, Jacobson GL, Webb T (1988) Paleoecology and the coarse filter approach to maintaining biological diversity. Conserv Biol 2:375-385

Jackson GL, Racey JG, McNicol JG, Godwin LA (1991) Moose habitat interpretation in Ontario. Ontario Department of Natural Resources NWOFTDU Tech Rep 52:1-74

Jalkotzy MG, Ross PI, Nasserden MD (1997) The effects of linear developments on wildlife: a review of selected scientific literature. Prepared for Canadian Association of Petroleum Producers, Arc Wildlife Services Ltd, Calgary, AB

Jordan PA (1987) Aquatic foraging and the sodium ecology of moose: a review. Swed Wildl Res Viltrevy Suppl 1:119-137

Joyal R (1987) Moose habitat investigations in Quebec and management implications. Swed Wildl Res Viltrevy Suppl 1:139-152

Joyal R, Scherrer B (1978) Summer movements and feeding by moose in western Quebec. Can Field-Nat 92:252-258

Karns PD 1967 Pneumostrongylus tenuis in deer in Minnesota and implications for moose. J Wildl Manag 31:299-303

Karns PD (1987) Moose population dynamics in North America. Swed Wildl Res Viltrevy Suppl 1:423-430

Kearney SR, Gilbert FF (1976) Habitat use by white-tailed deer and moose on sympatric range. J Wildl Manag 40:645-657

Kelsall JP (1987) The distribution and status of moose (A/ces alces) in North America. Swed Wildl Res Viltrevy Suppl 1:1-10

Kistchinski AA (1974) The moose in north-east Siberia. Nat Can (Que)101:179-184

Knowlton FF (1960) Food habits, movements and populations of moose in the Gravelly Mountains, Montana. J Wildl Manag 24:162-170

Krefting LW (1974) Moose distribution and habitat selection in north central North America. Nat Can (Que) 101:81-100

Kusnetsov K (1987) Habitat movements and interactions of moose with forest vegetation in USSR. Swed Wildl Res Viltrevy Suppl 1:201-211

Lacy RC (1993-1994) What is population (and habitat) viability analysis? Primate Conserv 14-15:27-33 
Lande $\mathbf{R}$ (1987) Extinction thresholds in demographic models of territorial populations. Am Nat 130:624-635

Lankester M (1987) Pests, parasites and diseases of moose in North America. Swed Wildl Res Viltrevy Suppl 1:461-490

Lankester M, Peterson WJ (1996) The possible importance of wintering yards in the transmission of Parelaphostrongylus tenuis to white-tailed deer and moose. J Wildl Dis 32:31-38

Larsen DG, Gauthier DA, Markel RL (1989) Causes and rate of moose mortality in the southwest Yukon. J Wildl Manag 53:548-557

Lehmkhul JF (1984) Determining size and dispersion of minimum viable populations for land management planning and species conservation. Environ Manag 8:167-176

Lehtonen A (1998) Managing moose, Alces alces, population in Finland: hunting virtual animals. Ann Zool Fenn 35:173-179

Leptich DJ, Gilbert JR (1986) Characteristics of moose calving sites in northern Maine as determined by multivariate analysis. N Am Moose Conf Worksh 22:69-82

Leptich DJ, Gilbert JR (1989) Summer home range and habitat use by moose in northern Maine. J Wildl Manag 53:880-885

LeResche RE, Bishop RH, Coady JW (1974) Distribution and habitats of moose in Alaska. Nat Can (Que) 101:143-178

Loucks OL (1962) A forest classification for the Maritime Provinces. Proc NS Inst Sci 25:85-167

Lovejoy TE (1992) Preface. In: Peters RL, LovejoyTE (eds) Global warming and biological diversity. Yale University Press, New Haven, CT, p xvii-xix

Lynch GM, Morgantini LE (1984) Sex and age differential in seasonal home range size of moose in northcentral Alberta, 1971-1979. N Am Moose Conf Worksh 20:61-78

MacCracken JG, Van Ballenberghe V, Peek JM (1997) Habitat relationships of moose on the Copper River Delta in coastal south-central Alaska. Wildl Monogr 136:1-52

McNicol J (1990) Moose and their environment. In: Ontario Department of Natural Resources (ed) The moose in Ontario, Book 1 - Moose biology, ecology and management. Queen's Printer for Ontario, Toronto, p 11-18

McNicol JG, Gilbert FF (1987) Effect of policy on moose habitat management in Ontario forests. Swed Wildl Res Viltrevy Suppl 1:153-161

Messier F, Crete M (1984) Body condition and population regulation by food resources in moose. Oecologia 65:44-50

Metzgar LH, Bader M (1992) Large mammal predators in the northern Rockies: grizzly bears and their habitat. Northwest Environ J 8:231-233

Miquelle DG, Peek JM, Van Ballenberghe V (1992) Sexual segregation in Alaskan moose. Wildl Monogr 122:1-57

Monthey RW (1984) Effects of timber harvesting on ungulates in northern Maine. J Wildl Manag 48:279-285

Morash R (2000) (Nova Scotia Department of Natural Resources (NSDNR), Wolfville, NS). Personal communication

Muise R (2000) (Nova Scotia Department of Natural Resources (NSDNR), Wolfville, NS). Personal communication

Murphy DD, Weiss SB (1992) Effects of climate change on biological diversity in western North America. In: Peters RL, Lovejoy TE (eds) Global warming and biological diversity. Yale University Press, New Haven, CT, p 355-368

Mytton WR, Keith LB (1981) Dynamics of moose populations near Rochester, Alberta, 1975-1978. Can Field-Nat 95:39-49

Nette A (2000) (Nova Scotia Department of Natural Resources (NSDNR), Wolfville, NS). Personal communication 
Nette A (2000) (Nova Scotia Department of Natural Resources (NSDNR), Wolfville, NS). Unpublished data

Newmark WD (1985) Legal and biotic boundaries of western North American national parks: a problem of congruence. Biol Conserv 33:197-208

NSDLF (Nova Scotia Department of Lands and Forests) (undated) Moose. Wildl Inform Bull 3:1-19

NSDOE (Nova Scotia Department of the Environment) (2000) Natural landscapes of Nova Scotia: summary description. Protected Areas Division, NSDOE, Halifax

Nudds TD (1990) Retroductive logic in retrospect: the ecological effects of meningeal worms. J Wildl Manag 54:396-402

Nygren T (1987) The history of moose in Finland. SwedWildl Res Viltrevy Suppl 1:49-54

Oldemeyer JL, Regelin WL (1987) Forest succession, habitat management, and moose on the Kenai National Wildlife Refuge. Swed Wildl Res Viltrevy Suppl 1:163-179

Oldemyer JL (1974) The nutritive value of moose forage. Nat Can (Que) 101:217-226

Outridge PM, MacDonald DD, Porter E, Cuthbert ID (1994) An evaluation of the ecological hazards associated with cadmium in the Canadian environment. Environ Rev 3:91-107

Page R (1987) Integration of populations dynamics for moose management. Swed Wildl Res Viltrevy Suppl 1:491-501

Peek JM (1974a) Initial response of moose to a forest fire in northeastern Minnesota. Amer Midl Nat 91:435-438

Peek JM (1974b) On the nature of winter habitats of Shiras moose. Nat Can (Que) 101:131-141

Peek JM, Pierce DJ, Graham DC, Davis DL (1987) Moose habitat use and implications for forest management in northcentral Idaho. SwedWildl Res Viltrevy Suppl 1:195-199

Peek JM, Urich DL, Mackie RJ (1976) Moose habitat selection and relationships to forest management in northeastern Minnesota. Wildl Monogr 48:1-65

Peters RL (1992) Conservation of biodiversity in the face of climate change. In: Peters RL, Lovejoy TE (eds) Global warming and biological diversity. Yale University Press, New Haven, CT, p 15-30

Peters RL, Darling JDS (1985) The greenhouse effect and nature reserves. BioScience 35:707-717

Peterson RL (1955) North American Moose. University of Toronto Press, Toronto

Phillips RL, Berg WE, Siniff DB (1973) Moose movement patterns and range use in northwestern Minnesota. J Wildl Manag 37:266-278

Pierce DJ, Peek JM (1984) Moose habitat use and selection patterns in north-central Idaho. J Wildl Manag 48:1335-1343

Post E, Stenseth NC (1998) Large-scale climatic fluctuation and population dynamics of moose and white-tailed deer. J Anim Ecol 67:537-543

Potvin F, Courtois R, Belanger L (1999) Short-term response of wildlife to clear-cutting in Quebec boreal forest: multiscale effects and management implications. Can J For Res 29:1120-1127

Prescott WH (1968) A study of winter concentration areas and food habits of moose in Nova Scotia. MSc thesis, Acadia University, Wolfville, NS

Prescott WH (1974) Interrelationships of moose and deer of the genus Odocoileus. Nat Can (Que) 101:493-504

Pulsifer M (1995) Moose herd perseveres. NS Conserv 19:6-7

Pulsifer M (2000) (Nova Scotia Department of Natural Resources (NSDNR), Wolfville, NS). Personal communication 
Pulsifer MD, Nette TL (1995) History, status and present distribution of moose in Nova Scotia. N Am Moose Conf Worksh 31:209-219

Puttock GD, Shakotko P, Rasaputra JG (1996) An empirical habitat model for moose, Alces alces, in Algonquin Park, Ontario. For Ecol Manag 81:169-178

Quinlan RW, Hunt WA, Wilson K, Kerr J (1990) Habitat requirements of selected wildlife species in the Weldwood Forest Management Area. Alberta Department of Forestry, Lands and Wildlife, Edmonton, AB

Raymond KS, Servello FA, Griffith B, Eschholz WE (1996) Winter foraging ecology of moose on glyphosate-treated clearcuts in Maine. J Wildl Manag 60:753-763

Reed JM, Doerr PD, Walters JR (1986) Determining minimum population sizes for birds and mammals. Wildl Soc Bull 14:255-261

Reed JM, Murphy DD, Brussard PF (1998) Efficacy of population viability analysis. Wildl Soc Bull 26:244-251

Regelin WL, Schwartz CC, Franzmann AW (1987) Effects of forest succession on nutritional dynamics of moose forage. Swed Wildl Res Viltrevy Suppl 1:247-263

Rempel RS, Elkie PC, Rodgers AR, Gluck MJ (1997) Timber-management and naturaldisturbance effects on moose habitat: landscape evaluation. JWildl Manag 61:517-524

Renecker LA, Hudson RJ (1986) Seasonal energy expenditures and thermoregulatory responses of moose. Can J Zool 64:322-327

Rowe JS (1972) Forest regions of Canada. Canadian Forestry Service, Department of Fisheries and Environment, Ottawa

Ryman N, Baccus R, Reuterwall C, Smith MH (1981) Effective population size, generation interval, and potential loss of genetic variability in game species under different hunting regimes. Oikos 36:257-266

Saether B-E (1997) Environmental stochasticity and population dynamics of large herbivores: a search for mechanisms. Trends Ecol Evol 12:143-149

Saether B-E, Andersen R, Hjeljord O, Heim M (1996) Ecological correlates of regional variation in life history of the moose Alces alces. Ecol 77:1493-1502

Samson FB (1983) Minimum viable populations - a review. Nat Areas J 3:15-23

Samson FB, Perez-Trejo F, Salwasser H, Ruggiero LF, Shaffer ML (1985) On determining and managing minimum population size. Wildl Soc Bull 13:425-433

Samuel WM (1991) Grooming by moose (A/ces alces) infested with the winter tick, Dermacentor albipictus (Acari): a mechanism for premature loss of winter hair. Can J Zool 69:1255-1260

Samuel WM, Welch DA, Drew ML (1986) Shedding of the juvenile and winter hair coats of moose (A/ces alces) with emphasis on the influence of the winter tick, Dermacentor albipictus. N Am Moose Conf Worksh 22:345-360

Sand H, Bergstrom R, Cederlund G, Ostergren M, Stafelt F (1996) Density-dependent variation in reproduction and body mass in female moose Alces alces. Wildl Biol 2:233-245

Santillo DJ (1994) Observations on moose, Alces alces, habitat and use on herbicidetreated clearcuts in Maine. Can Field-Nat 108:22-25

Saunders BP (1973) Meningeal worm in white-tailed deer in northwestern Ontario and moose population densities. J Wildl Manag 37:327-330

Scanlon PF, Morris KI, Clark AG, Fimreite N, Lierhagen S (1986) Cadmium in moose tissues: comparison of data from Maine, USA and from Telemark, Norway. N Am Moose Conf Worksh 22:303-312

Schwab FE (1985) Moose habitat selection in relation to forest cutting practices in Northcentral British Columbia. PhD thesis, University of British Columbia, Vancouver 
Schwab FE, Pitt MD (1991) Moose selection of canopy cover types related to operative temperature, forage and snow depth. Can J Zool 69:3071-3077

Schwartz CC, Regelin WL, Franzmann A, Hubbert MW (1987) Nutritional energetics of moose. Swed Wildl Res Viltrevy Suppl 1:265-279

Selenius O, Frank A (2000) Medical geology. In: Moller L (ed) Environmental medicine. Joint Industrial Safety Council, Stockholm, p 164-183

Selenius O, Frank A, Galgan V (1996) Biogeochemistry and metal biology. Geological Society Special Publication: Environ Geochem Health 113:81-89

Shaffer ML (1981) Minimum population sizes for species conservation. BioScience 31:131-134

Shaffer ML (1983) Determining minimum viable population sizes for the grizzly bear. International Conference on Bear Research and Management 5:133-139

Shaffer ML (1990) Population viability analysis. Conserv Biol 4:39-40

Shugart HH, Smith TM (1992) Using computer models to project ecosystem response, habitat change and wildlife diversity. In: Peters RL, Lovejoy TE (eds) Global warming and biological diversity. Yale University Press, New Haven, CT, p 147-157

Snaith TV (2001) Moose in Nova Scotia: Population viability and habitat suitability. MSc thesis, Dalhousie University, Halifax

Snaith TV, Beazley KF (2003) Population viability: theory and application to moose in mainland Nova Scotia, Canada. N Am Moose Conf Worksh 38:1-11

Solberg EJ, Saether B-E (1999) Hunter observations of moose Alces alces as a management tool. Wildl Biol 5:107-117

Solberg EJ, Saether B-E, Strand O, Loison A (1999) Dynamics of a harvested moose population in a variable environment. J Anim Ecol 68:186-204

Soulé ME (1980) Thresholds for survival: maintaining fitness and evolutionary potential. In: Soulé ME, Wilcox BA (eds) Conservation biology: an evolutionary-ecological perspective. Sinauer Associates, Sunderland, MA, p 151-169

Stenhouse GB (1995) Productivity, survival and movements of female moose in a low density population, Northwest Territories, Canada. Arctic 48:57-62

Stevens DR (1970) Winter ecology of moose in the Gallatin Mountains, Montana. J Wildl Manag 34:37-46

Strandgaard S (1982) Factors affecting the moose population in Sweden during the 20th century with special attention to silviculture. Rapp Intitut Viltrekologi 8:1-31

Sumanik KM, Demarchi D (1977) Dispersion and relative abundance of moose in northern British Columbia. N Am Moose Conf Worksh 13:252-257

Sweanor PY, Sandegren F (1989) Winter-range philopatry of seasonally migratory moose. J Appl Ecol 26:25-33

Syroechkovskiy EE, Rogacheva EV (1974) Moose of the Asiatic part of the USSR. Nat Can (Que) 101:595-604

Taylor KB, Ballard WB (1979) Moose movements and habitat use along the Susitna River near Devil's Canyon. N Am Moose Conf Worksh 15:169-186

Telfer ES (1967a). Comparison of a deer yard and a moose yard in Nova Scotia. Can J Zool 45:485-490

Telfer ES (1967b) Comparison of moose and deer winter range in Nova Scotia. J Wildl Manag 31:418-425

Telfer ES (1968a) Distribution and association of moose and deer in central New Brunswick. Trans Northeast Sec Wildl Soc 25:41-70

Telfer ES (1968b) The status of moose in Nova Scotia. J Mammal 49:325-326

Telfer ES (1970a) Relationships between logging and big game in eastern Canada. Pulp and Paper Magazine of Canada, October 2, 1970:3-7 
Telfer ES (1970b) Winter habitat selection by moose and white-tailed deer. J Wildl Manag 34:553-558

Telfer ES (1984) Circumpolar distribution and habitat requirements of moose (A/ces alces). In: Olson R, Hastings R, Geddes F (eds) Northern ecology and resource management. University of Alberta Press, Edmonton, p 145-182

Telfer ES (1995) Moose range under presettlement fire cycles and forest management regimes in the boreal forest of western Canada. NAm Moose ConfWorksh 31:153-165

Telfer ES, Cairns AL (1986) Resource use by moose versus sympatric deer, wapiti and bison. N Am Moose Conf Worksh 22:113-137

Terborgh J, Winter B (1980) Some causes of extinction. In: Soulé ME, Wilcox ME (eds) Conservation biology: an evolutionary-ecological perspective. Sinauer Associates, Sunderland, MA, p 119-134

Theberge JB (1993) Ecology, conservation and protected areas in Canada. In: Dearden P, Rollins R (eds) Parks and protected areas in Canada. Oxford University Press, Don Mills, ON, p 137-153

Thomas CD (1990) What do real population dynamics tell us about minimum viable population sizes. Conserv Biol 4:324-327

Thomas JE, Dodds DG (1988) Brainworm, Paralephostrongylus tenuis, in moose, Alces alces, and white-tailed deer, Odocoileus virginianus, of Nova Scotia. Can Field-Nat 102:639-642

Thompson ID, Euler DL (1987) Moose habitat in Ontario: a decade of change in perception. Swed Wildl Res Viltrevy Suppl 1:181-193

Thompson ID, Vukelich MF (1981) Use of logged habitats in winter by moose cows with calves in northeastern Ontario. Can J Zool 59:2103-2114

Thompson ME, Gilbert JR, Matula GJ, Morris KI (1995) Seasonal habitat use by moose on managed forest lands in northern Maine. N Am Moose Conf Worksh 31:233-245

Tierson WC, Mattfield GF, Sage RW, Behrend DF (1985) Seasonal movements and home ranges of white-tailed deer in the Adirondacks. J Wildl Manag 49:760-769

Timmerman HR, McNicol JG (1988) Moose habitat needs. Forestry Chron June 1988:238-245

Timmermann HR (1990) Basic moose biology. In: Ontario Department of Natural Resources (ed) The moose in Ontario, Book 1 - Moose biology, ecology and management. Queen's Printer for Ontario, Toronto, p 1-10

Timmermann HR, Gollath R (1982) Age and sex structure of harvested moose related to season manipulation and access. N Am Moose Conf Worksh 18:301-328

Timmermann HR, Buss ME (1997) The status and management of moose in Northern America in the early 1990s. Ontario Department of Natural Resources, Thunder Bay, ON

Tomm HO, Beck JA Jr (1981) Responses of wild ungulates to logging practices in Alberta. Can J For Res 11:606-614

Towry RK (1984) Wildlife habitat requirements. In: Hoover RL, Wills DL (eds) Managing forested lands for wildlife. Colorado Division of Wildlife in cooperation with the USDA Forest Service, Rocky Mountain Region, Denver, p 73-211

van BallenbergheV, Ballard WB (1994) Limitation and regulation of moose populations: the role of predation. Can J Zool 72:2071-2077

van Ballenberghe V, Peek JM (1971) Radiotelemetry studies of moose in northeastern Minnesota. J Wildl Manag 35:63-71

Vivas HJ, Saether B-E (1987) Interactions between a generalist herbivore, the moose Alces alces, and its food resources: an experimental study of winter foraging behaviour in relation to browse availability. J Anim Ecol 56:509-520 
Wallin K, Bergstrom R, Vikberg (1995) Population density and inbreeding effect on moose Alces alces reproduction. Wildl Biol 1:225-231

Wangersky R (2000) Too many moose? Can Geogr, Nov/Dec:44-56

Whitlaw HA, Lankester $\mathbf{M}$ (1994) A retrospective evaluation of the effects of Parelaphostongylosis on moose populations. Can J Zool 72:1-7

Wilson EO (1975) Sociobiology. Belknap Press, Cambridge, MA

Wolfe ML (1987) An overview of the socioeconomics of moose in North America. Swed Wildl Res Viltrevy Suppl 1:659-675

Wright BS (1956) The moose of New Brunswick. New Brunswick Department of Lands and Mines, Fredericton, NB 


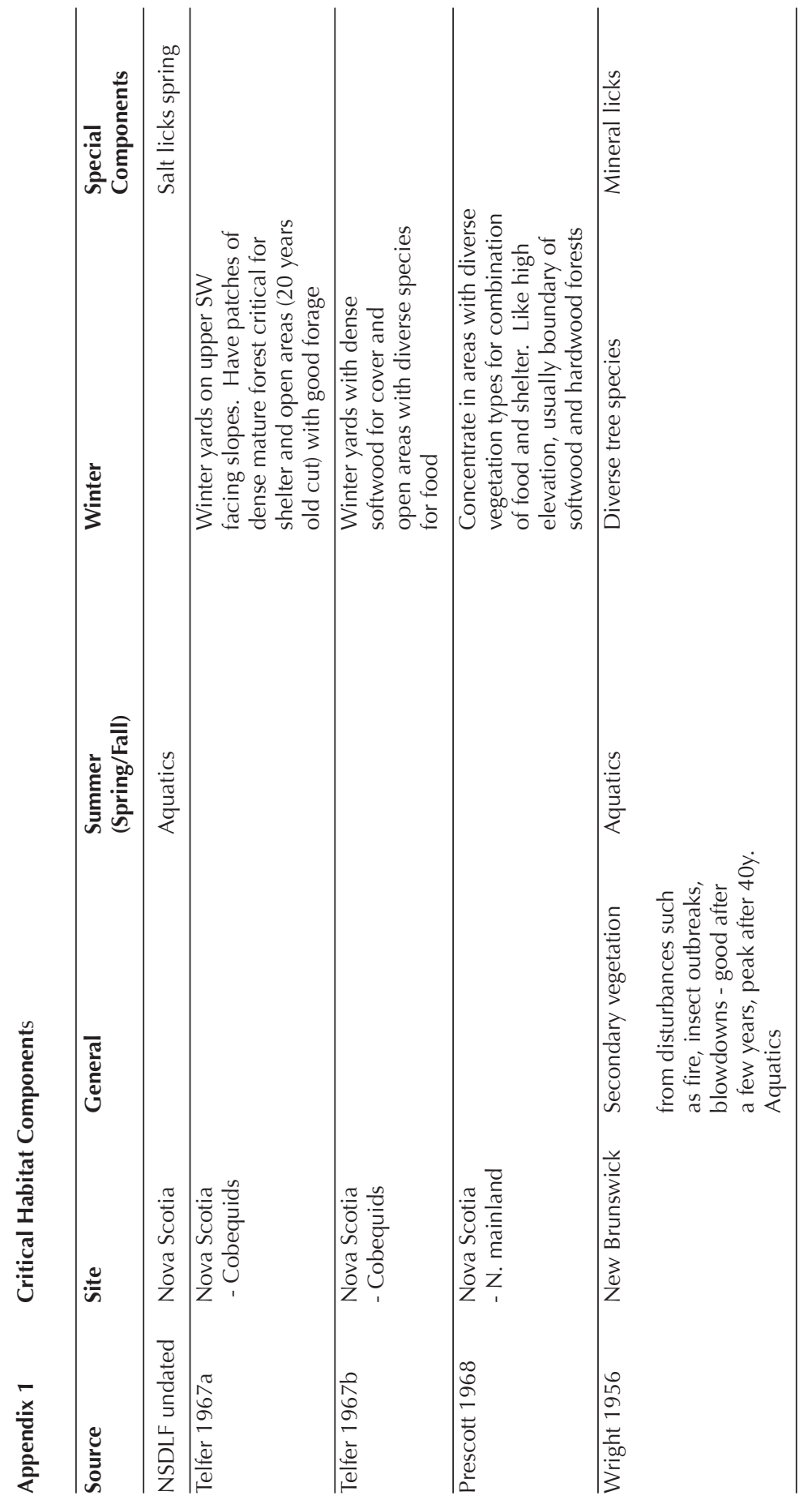




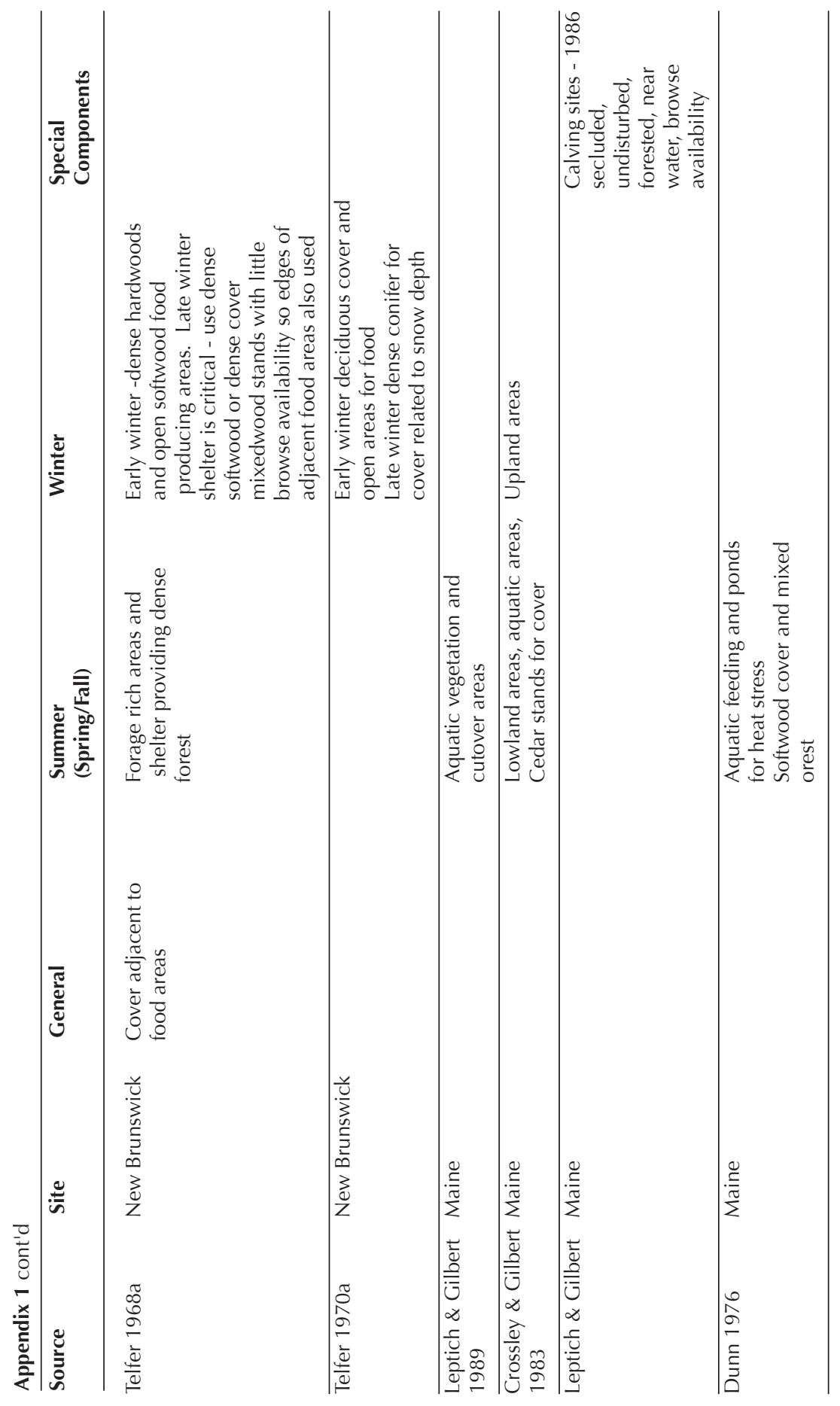




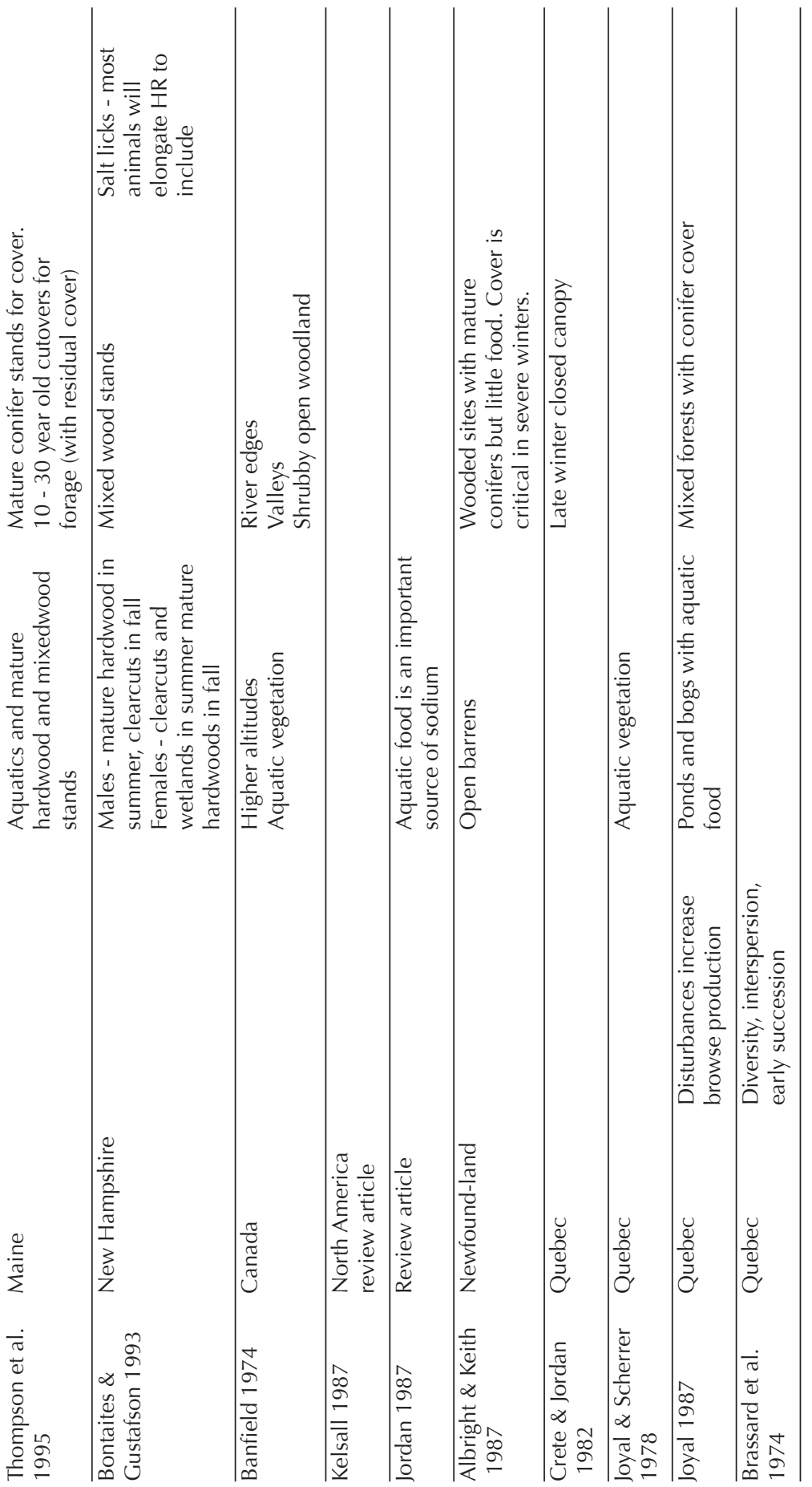




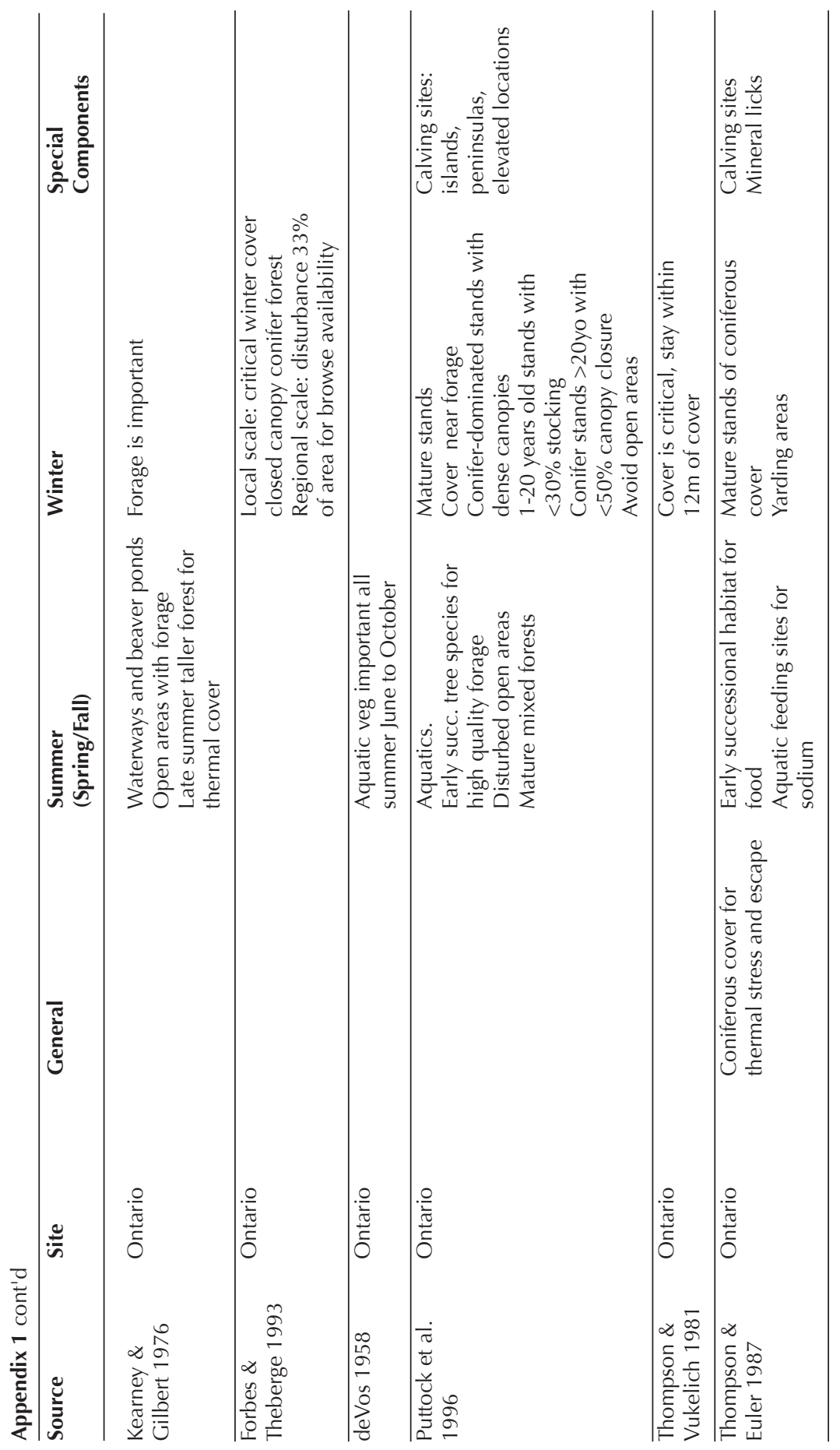




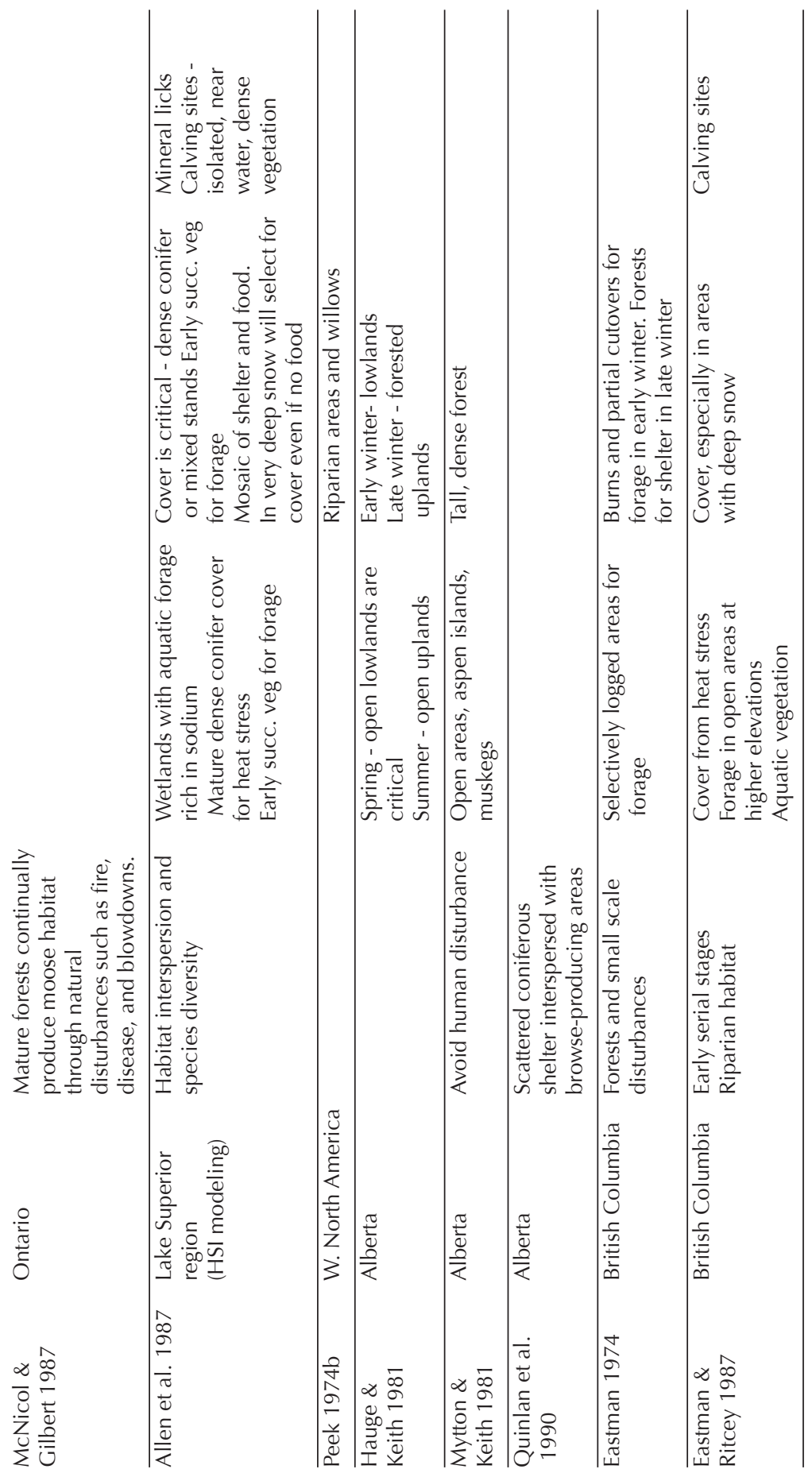




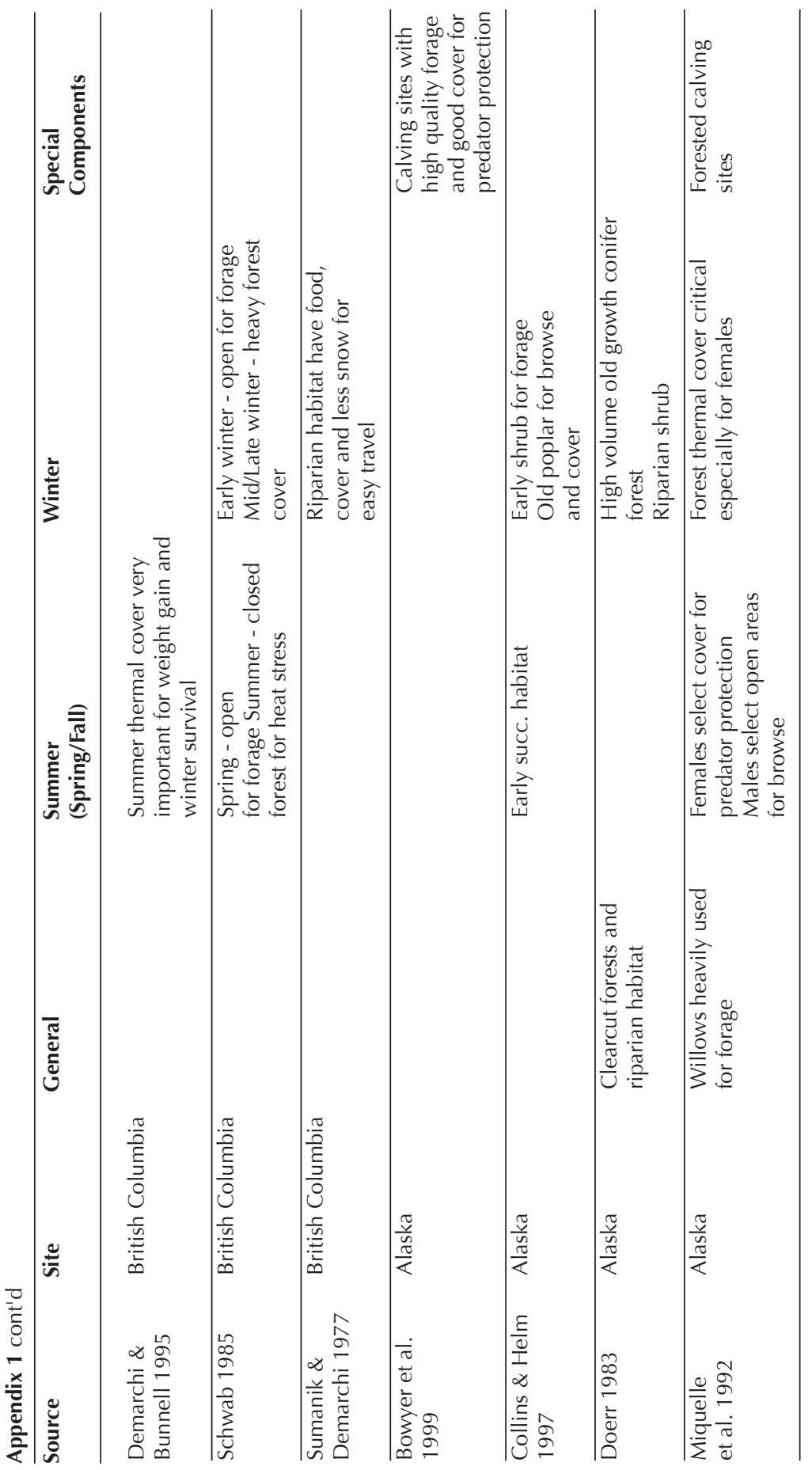




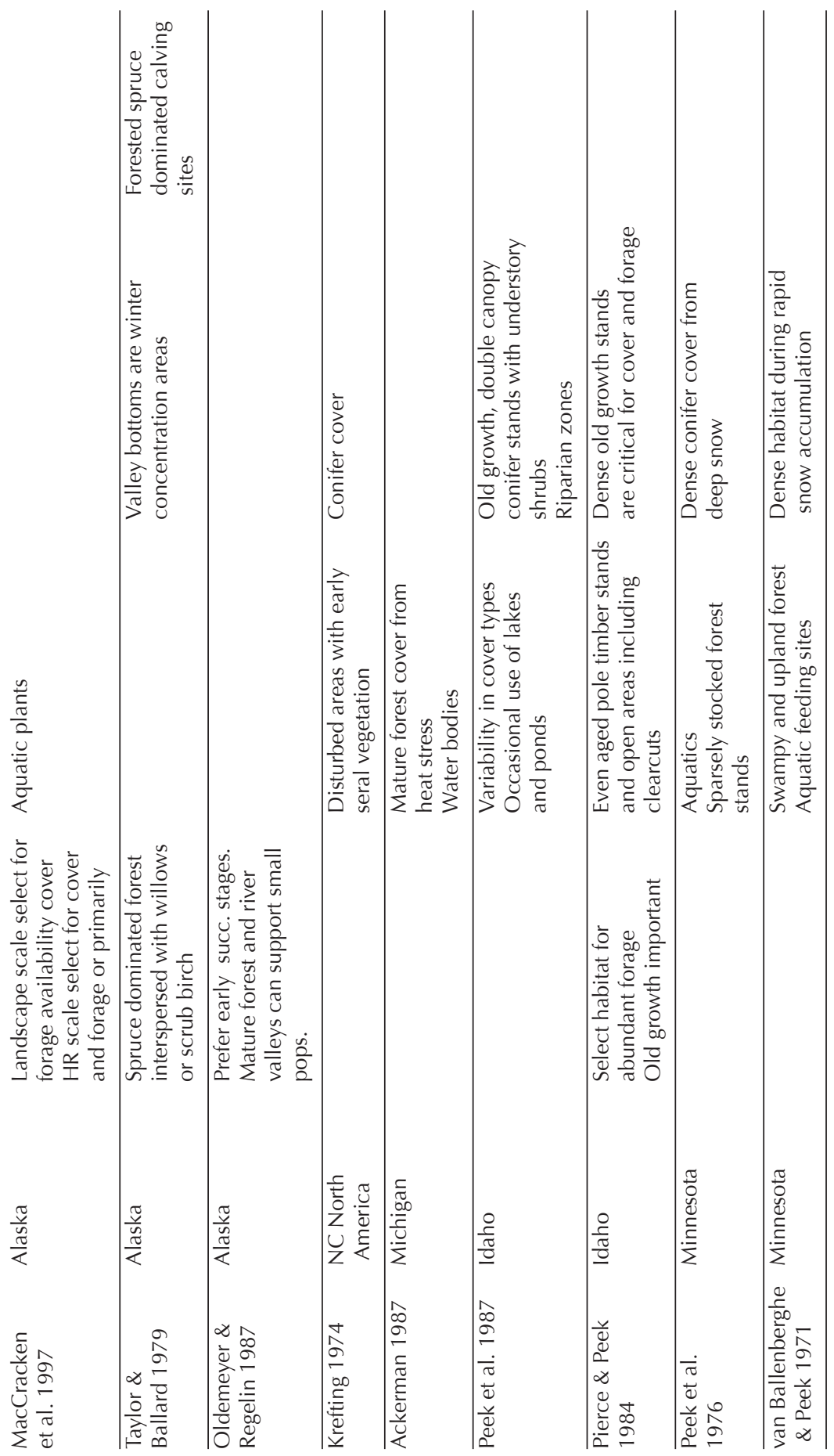




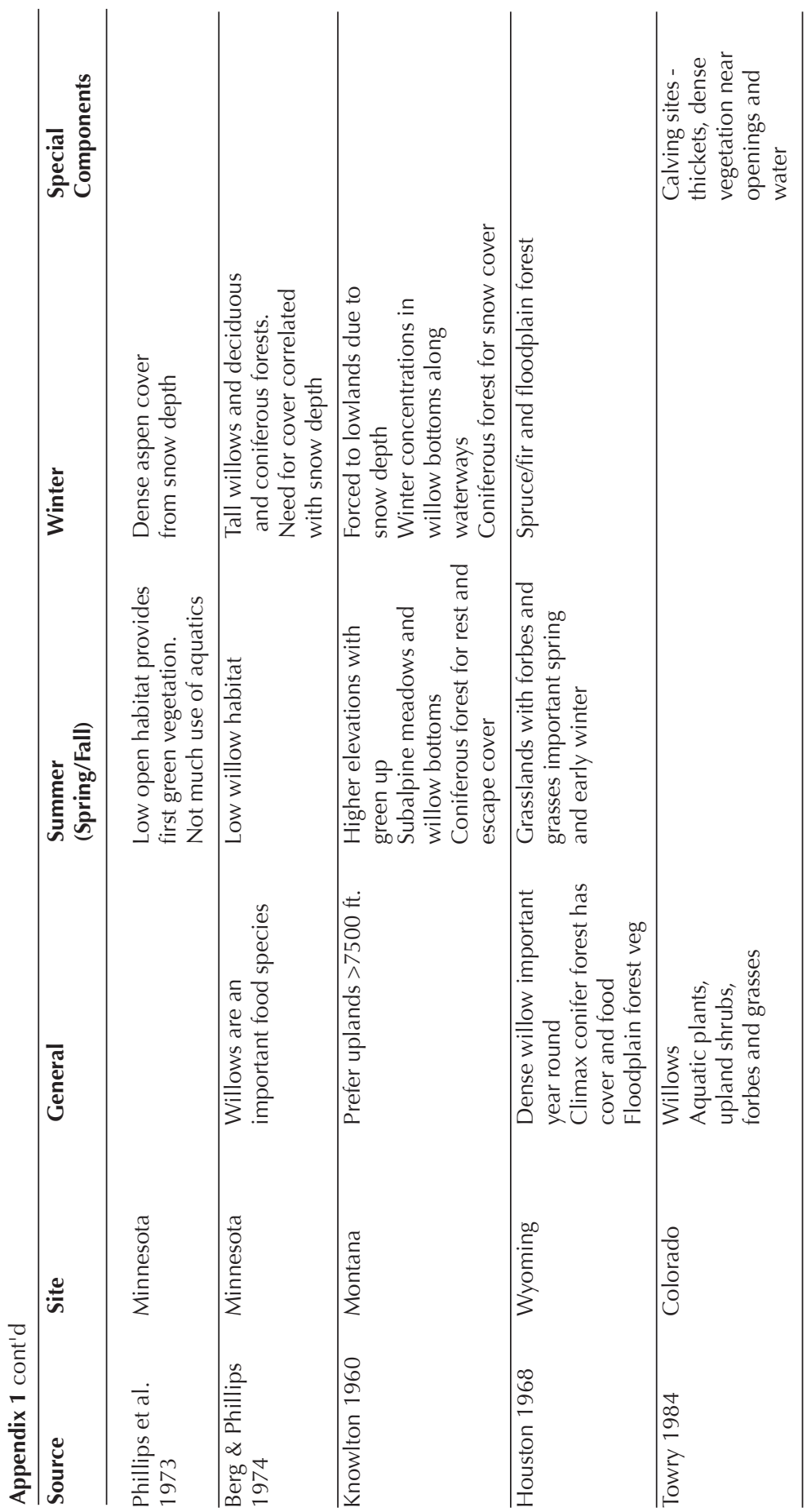




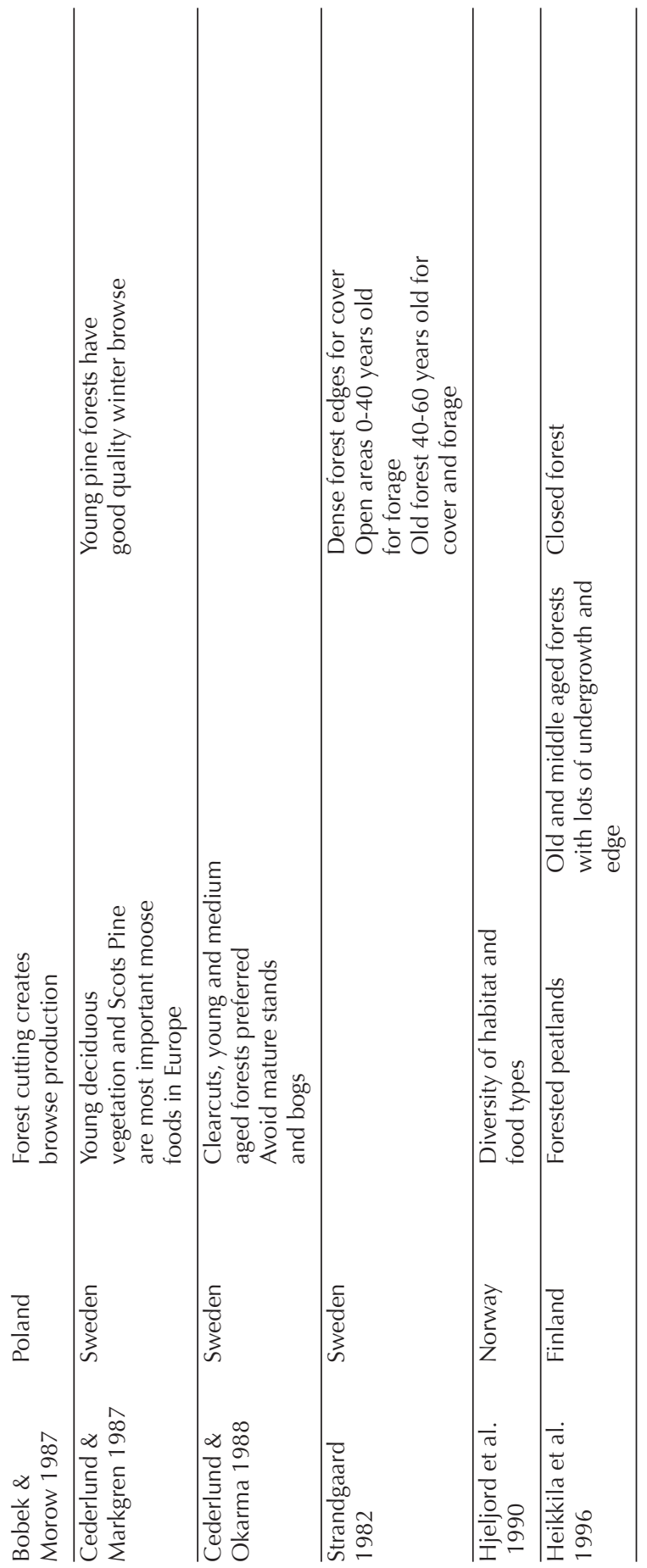


Appendix 2 Moose Food Preferences by Species

\begin{tabular}{|c|c|c|}
\hline Source & Site & Food Species \\
\hline Benson 1957 & Nova Scotia & $\begin{array}{l}\text { Winter: } \\
\text { Fir (Abies spp.) } \\
\text { White birch (Betula papyrifera) } \\
\text { Yellow birch (Betula alleghaniensis) } \\
\text { Beaked hazelnut (Corylus cornuta) } \\
\text { Maples (Acer sp.) } \\
\text { Available but not eaten: } \\
\text { Spruce (Picea sp.) } \\
\text { Wire birch (Betula sp.) } \\
\text { Beech (Fagus grandifolia) }\end{array}$ \\
\hline Prescott 1968 & $\begin{array}{l}\text { Nova Scotia } \\
\text { N. mainland }\end{array}$ & $\begin{array}{l}\text { Mountain maple (Acer spicatum) } \\
(25.5 \% \text { of diet; } 15.9 \% \text { of available food) } \\
\text { Yellow birch (Betula lutea) }(19.9 \% ; 9.5 \%) \\
\text { Sugar maple (Acer saccharum) }(16.5 \% ; 15 \%) \\
\text { Balsam fir (Abies balsamea) }(13.6 \% ; 16.2 \%) \\
\text { Red maple (Acer rubrum) }(8.5 \% ; 6.4 \%) \\
\text { Hazel (Corylus cornuta) }(6.1 \% ; 2.5 \%) \\
\text { Elderberry (Sambucus pubens) }(1.4 \% ; 2.2 \%) \\
\text { Striped maple (Acer pensylvanicum) }(1.4 \% ; 0.9 \%) \\
\text { White birch (Betula papyrifera) }(1.2 \%, 2.1 \%) \\
\text { Honeysuckle (Lonicera canadensis) }(1.1 \% ; 6.8 \%) \\
\text { Beech (Fagus grandifolia) }(0.9 \% ; 1.6 \%) \\
\text { Blackberry (Rubus allegheniensis) }(0.7 \% ; 0.6 \%) \\
\text { Hobblebush (Viburnum alnifolium) }(0.6 \% ; 0.2 \%) \\
\text { Cornus spp. (Cornum spp.) }(0.6 \% ; 0.8 \%) \\
\text { Raspberry (Rubus stringosus) }(0.6 \% ; 12.2 \%) \\
\text { Cherry (Prunus pensylvanica) }(0.5 \% ; 1.8 \%) \\
\text { Willow (Salix spp.) (0.5; } 0.1) \text { imp. at low elev. } \\
\text { Ribes spp. (Ribes spp.) (0.1\%; } 2.3 \%) \\
\text { Available but not eaten: } \\
\text { Red spruce (Picea rubens) } \\
\text { White ash (Fraxinus americana) } \\
\text { Yew (Taxus canadensis) } \\
\text { Mountain Ash (Sorbus americana) } \\
\text { Speckled Alder (Alnus rugosa) } \\
\text { Blueberry (Vaccinium myrtilloides) } \\
\text { White spruce (Picea glauca) } \\
\text { Rose sp. (Rosa sp.) }\end{array}$ \\
\hline Telfer 1967a & $\begin{array}{l}\text { Nova Scotia } \\
\text { Cobequids }\end{array}$ & $\begin{array}{l}\text { Winter concentration areas: } \\
\text { Balsam fir (Abies balsamea) } \\
\text { White birch (Betula papyrifera) } \\
\text { Yellow birch (Betula alleghaniensis) } \\
\text { Sugar maple (Acer saccharum) }\end{array}$ \\
\hline Telfer 1967b & $\begin{array}{l}\text { Nova Scotia } \\
\text { Cobequids }\end{array}$ & $\begin{array}{l}\text { Winter } \\
\text { Maples (Acer rubrum, A. saccharum, A. spicatum) } \\
\text { (50\% of diet) } \\
\text { Yellow birch (Betula alleghaniensis) (18\%) } \\
\text { Balsam fir (Abies balsamea) (small amount) }\end{array}$ \\
\hline
\end{tabular}


Appendix 2 cont'd

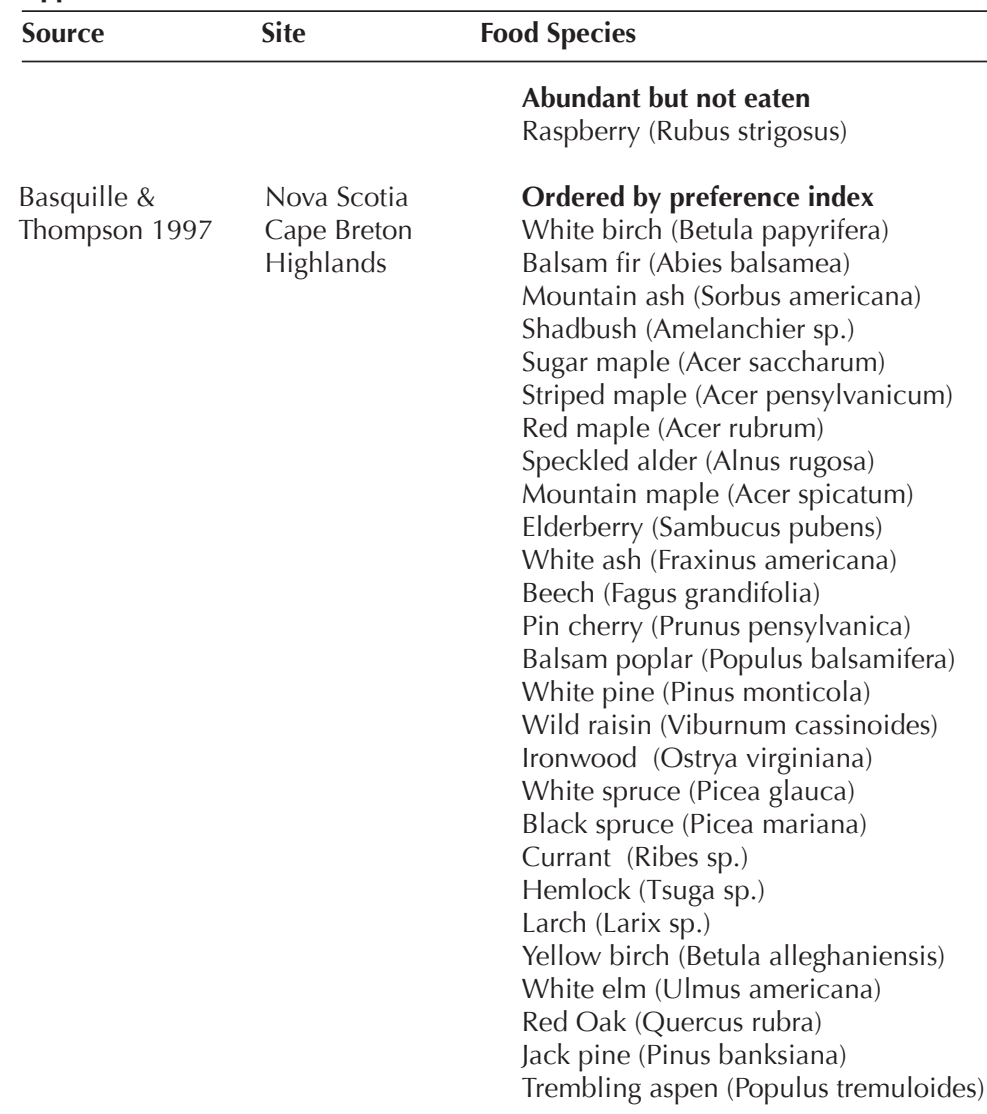

Telfer 1968a

Wright 1956
New Brunswick

\section{Early winter:}

Red maple (Acer rubrum)

Wild raisin (Viburnum cassinoides)

Striped maple (Acer pensylvanicum)

Beaked hazel (Corylus cornuta)

Mountain maple (Acer spicatum)

Sugar maple (Acer saccharum)

\section{New Brunswick Winter: Heavy use:}

Gray birch (Betula populifolia)

Yellow birch (Betula alleghaniensis)

White birch (Betula papyrifera)

Red maple (Acer rubrum)

Striped maple (Acer pensylvanicum)

Willow (Salix sp.)

Aspen (Populus sp.)

White cedar (Thuja sp.)

Viburnum (Viburnum sp.)

Cherry (Prunus sp.)

Hard maple (Acer sp.) 
Appendix 2 cont'd

\begin{tabular}{|c|c|c|}
\hline Source & Site & Food Species \\
\hline & & $\begin{array}{l}\text { Leatherleaf (Chamaedaphne calyculata) } \\
\text { Slight/moderate use: } \\
\text { Balsam fir (Abies balsamea) } \\
\text { Alder (Alnus sp.) } \\
\text { White pine (Pinus monticola) } \\
\text { Raspberry (Rubus sp.) } \\
\text { Silver maple (Acer saccharinum) } \\
\text { Hazel (Corylus cornuta) } \\
\text { Oak (Quercus sp.) } \\
\text { Present but NOT eaten: } \\
\text { White spruce (Picea glauca) } \\
\text { Black spruce (Picea mariana) } \\
\text { Tamarack (Larix laricina) } \\
\text { Hemlock (Tsuga sp.) } \\
\text { Beech (Fagus grandifolia) } \\
\text { Shadbush (Amelanchier sp.) }\end{array}$ \\
\hline Crete 1987 & $\begin{array}{l}\text { Quebec Gaspe } \\
\text { Peninsula }\end{array}$ & $\begin{array}{l}\text { Winter: } \\
\text { White birch (Betula papyrifera) (49\% of diet; } \\
\quad 7 \% \text { of available biomass) } \\
\text { Balsam fir (Abies balsamea) (19\%; 88\%) } \\
\text { Mountain maple (Acer spicatum) }(10 \% ; 1 \%) \\
\text { Amelanchier (Amelanchier sp.) }(9 \% ; 2 \%) \\
\text { Red-osier dogwood (Cornus stolonifera) }(6 \% ; 1 \%) \\
\text { Cranberrybush (Viburnum edule) }(3 \% ; 1 \%) \\
\text { Willow (Salix sp.) }(2 \% ;<1 \%) \\
\text { Mountain ash (Sorbus americana) }(1 \% ;<1 \%) \\
\text { Alder (Alnus crispa) }(1 \% ;<1 \%) \\
\text { Quaking aspen (Populus tremuloides) }(<1 \% ;<1 \%) \\
\text { Pin cherry (Prunus pensylvanica) }(<1 \% ;<1 \%)\end{array}$ \\
\hline $\begin{array}{l}\text { Raymond et al. } \\
1996\end{array}$ & Maine & $\begin{array}{l}\text { Paper birch (Betula papyrifera) } \\
\text { Pin cherry (Prunus pensylvanica) } \\
\text { Aspen (Populus tremuloides and P. grandidentata) } \\
\text { Red maple (Acer rubrum) } \\
\text { Yellow birch (Betula alleghaniensis) } \\
\text { Striped maple (Acer pensylvanicum) } \\
\text { Sugar maple (Acer saccharum) } \\
\text { Mountain maple (Acer spicatum) } \\
\text { Willow (Salix sp.) } \\
\text { Mountain ash (Sorbus americana) } \\
\text { Balsam fir (Abies balsamea) }\end{array}$ \\
\hline $\begin{array}{l}\text { Crossley \& } \\
\text { Gilbert } 1983\end{array}$ & Maine & $\begin{array}{l}\text { Winter: } \\
\text { Balsam fir (Abies balsamea) } \\
\text { Quaking aspen (Populus tremuloides) } \\
\text { Paper birch (Betula papyrifera) }\end{array}$ \\
\hline Telfer 1984 & $\begin{array}{l}\text { Atlantic Canada } \\
\text { and } \\
\text { New England }\end{array}$ & $\begin{array}{l}\text { Mountain maple (Acer spicatum) } \\
\text { Striped maple (A. pensylvanicum) } \\
\text { Wild raisin (Viburnum cassinoides) } \\
\text { Witch Hazel (Hammalis virginiana) }\end{array}$ \\
\hline
\end{tabular}


Appendix 2 cont'd

\begin{tabular}{lll}
\hline Source & Site & Food Species \\
\hline & Blueberry (Vaccinium sp.) \\
& Fir (Abies sp.) \\
& Birch (Betula sp.) \\
& Aspen (Populus sp.) \\
& Winter: \\
& Willows (Salix spp.) \\
& Balsam fir (Abies balsamea) \\
& Red-osier dogwood (Cornus stolonifera) \\
& Mountain ash (Sorbus americana) \\
& Aspen (Populus grandidentata) \\
& Birch (Betula spp.) \\
& Beaked Hazel (Corylus cornuta) \\
& Balsam (Abies balsamea) \\
& Poplar (Populus balsamifera) \\
& Pin Cherry (Prunus pensylvanica) \\
& Maple (Acer spp.) \\
& Viburnum (Viburnum spp.) \\
\hline
\end{tabular}

Some species/common names from Rowe (1972) 
Appendix 3 Forestry and Management Recommendations

\begin{tabular}{|c|c|c|}
\hline Source & Site & Forestry and Management \\
\hline$\overline{\text { Prescott } 1968}$ & $\begin{array}{l}\text { Nova Scotia } \\
- \text { N. mainland }\end{array}$ & $\begin{array}{l}\text { Small scale disturbances like selective cutting arebeneficial } \\
\text { to moose because openings produce browse while } \\
\text { maintaining enough cover. } \\
\text { Bigger clearcuts not good because regeneration is } \\
\text { poor, edges of remaining cover sustain wind damage, } \\
\text { monoculture regeneration is no good. }\end{array}$ \\
\hline
\end{tabular}

Telfer 1968a

Telfer $1970 b$

Kelsall 1987

Joyal 1987

Brassard et al. Quebec 1974

Thompson

et al. 1995

Hogg 1990

Thompson \& Vukelich 1981

Maine
New Brunswick Cuttings adjacent to winter shelter will provide winter food.

Moose will not make use of forage in large open areas. Need detailed local information on moose habitat selection and ranging patterns.

New Brunswick $60-80 \%$ of an area should be $>35$ years old at all times. Need information on moose distribution and key habitat areas for consideration in forest management operations.

Clearcut patches or strips $<100$ feet wide and arranged to ensure adequate cover remains near forage production areas.

North America review article

Some management can improve habitat and allow expansion of moose range.

Quebec Logging provides short term benefit of increased browse production, peaks 5-15 y after cut. Leave ten 2-3 ha stands per $10 \mathrm{~km}^{2}$. Consider suitability of planted species. Large clearcutting reduces habitat, and if few small clumps of cover left behind, moose are trapped and vulnerable and must compete for small remaining areas.

Logging provides only short term benefits of early successional forage. Production of monocultures is poor moose habitat.

Moose will use cuts 10 to 30 years old for forage only if residual softwood stands remain for cover

Large cuts $>100$ ha must include shelter patches of $3-8$ ha or be shaped so never more than $200 \mathrm{~m}$ to cover. Harvesting and access roads located with care to avoid critical habitat components such as calving areas and aquatic feeding sites.

Ontario Moose use cuts after 18y post cut

Cows with calves rarely more than $60 \mathrm{~m}$ from cover 
Appendix 3 cont'd

\begin{tabular}{|c|c|c|}
\hline Source & Site & Food Species \\
\hline $\begin{array}{l}\text { Thompson \& } \\
\text { Euler } 1987\end{array}$ & Ontario & $\begin{array}{l}\text { Large clearcuts with successional vegetation not as useful } \\
\text { as small ones } \\
\text { Must leave some uncut areas }\end{array}$ \\
\hline $\begin{array}{l}\text { McNicol \& } \\
\text { Gilbert } 1987\end{array}$ & Ontario & $\begin{array}{l}\text { Irregular shaped cuts } \\
\text { Scattered shelter patches } \\
\text { Stands with diverse age/ species composition }\end{array}$ \\
\hline $\begin{array}{l}\text { Hamilton et al. } \\
1980\end{array}$ & N. Ontario & Use of clearcuts restricted to areas within $80 \mathrm{~m}$ of cover \\
\hline Allen et al. 1987 & $\begin{array}{l}\text { Lake Superior } \\
\text { region }\end{array}$ & $\begin{array}{l}\text { (HSI modeling) } \\
\text { Ideal year round habitat: } 40-50 \% \text { of area is sites with } \\
\text { ( } 50 \% \text { shrub or young forest }<20 y \text { o } \\
5-15 \% \text { conifer }>20 y 0 \\
35-55 \% \text { deciduous or mixed forest }>20 y \text { o } \\
5-10 \% \text { wetlands with aquatic foods } \\
\text { Food within } 100 \text { m of cover }\end{array}$ \\
\hline
\end{tabular}

Tomm \&

Beck 1981

$\begin{array}{ll}\text { Eastman } 1974 & \text { British } \\ & \text { Columbia }\end{array}$

Telfer 1995

Doerr 1983

Alaska

Oldemeyer \&

Regelin 1987

Peek et al. 1987

Idaho

Pierce \&

Peek 1984

Peek et al. 1976

Alberta

Western

Canada

Alaska
Moose use of cutblocks depends on the size of the cut, the interspersion of mature stands within the cut and levels of harassment.

Prefer cuts 0.17 to $0.32 \mathrm{~km}^{2}$ which are buffered from other openings by 200 to $400 \mathrm{~m}$ of forest

Recent clearcuts least used. Partially logged stands or burns 11-20 years old are important.

Stand conversion to conifers with control of deciduous vegetation may limit moose numbers

Uncontrolled human access may also limit numbers

Moose use cuts $<30$ years post cut

Manage large areas (2000ha management units). Intersperse undisturbed areas (40\%) with disturbances.

Moose did not use logged/open areas much even when available so management for early successional browse will not be effective for creating habitat.

Must retain at least $55 \%$ of area in mature forest.

Road closure following completion of operations.

Avoid timber harvest in old-growth forest.

Manage township sized areas with $40-50 \%$ cutover with $<20$ yo regeneration;

$5-15 \%$ spruce/fir cover; $35-55 \%$ aspen-white birch $>20 y$ and water

Cuts create browse but if plant with dense stocking or use herbicides or unfavoured species then habitat and browse decrease 
Appendix 3 cont'd

\begin{tabular}{|c|c|c|}
\hline Source Site & Food Species & \\
\hline Houston 1968 & Wyoming & $\begin{array}{l}\text { Human development will cause decreasing forage } \\
\text { availability ie. through road construction and campsite } \\
\text { development }\end{array}$ \\
\hline $\begin{array}{l}\text { Cederlund \& } \\
\text { Markgren } 1987\end{array}$ & Sweden & Clearcuts can provide high quality forage. \\
\hline $\begin{array}{l}\text { Strandgaard } \\
1982\end{array}$ & Sweden & $\begin{array}{l}\text { Clearcuts produce forage but pesticides decrease food } \\
\text { availability. } \\
\text { Older forest and dense edges also important. }\end{array}$ \\
\hline $\begin{array}{l}\text { Hjeljord et al. } \\
1990\end{array}$ & $\begin{array}{l}\text { Norway } \\
\text { older forests. }\end{array}$ & Benefit of a heterogeneous mixture of plantations and \\
\hline $\begin{array}{l}\text { Heikkila et al. } \\
1996\end{array}$ & Finland & $\begin{array}{l}\text { (Managed forest) Logging areas produce patchy habitat } \\
\text { with lots of food over a long period }\end{array}$ \\
\hline Kusnetsov 1987 & USSR & $\begin{array}{l}\text { Cutting creates more habitat /forage and can increase } \\
\text { population density beyond CC which becomes } \\
\text { detrimental to habitat / forage /forest regeneration }\end{array}$ \\
\hline
\end{tabular}




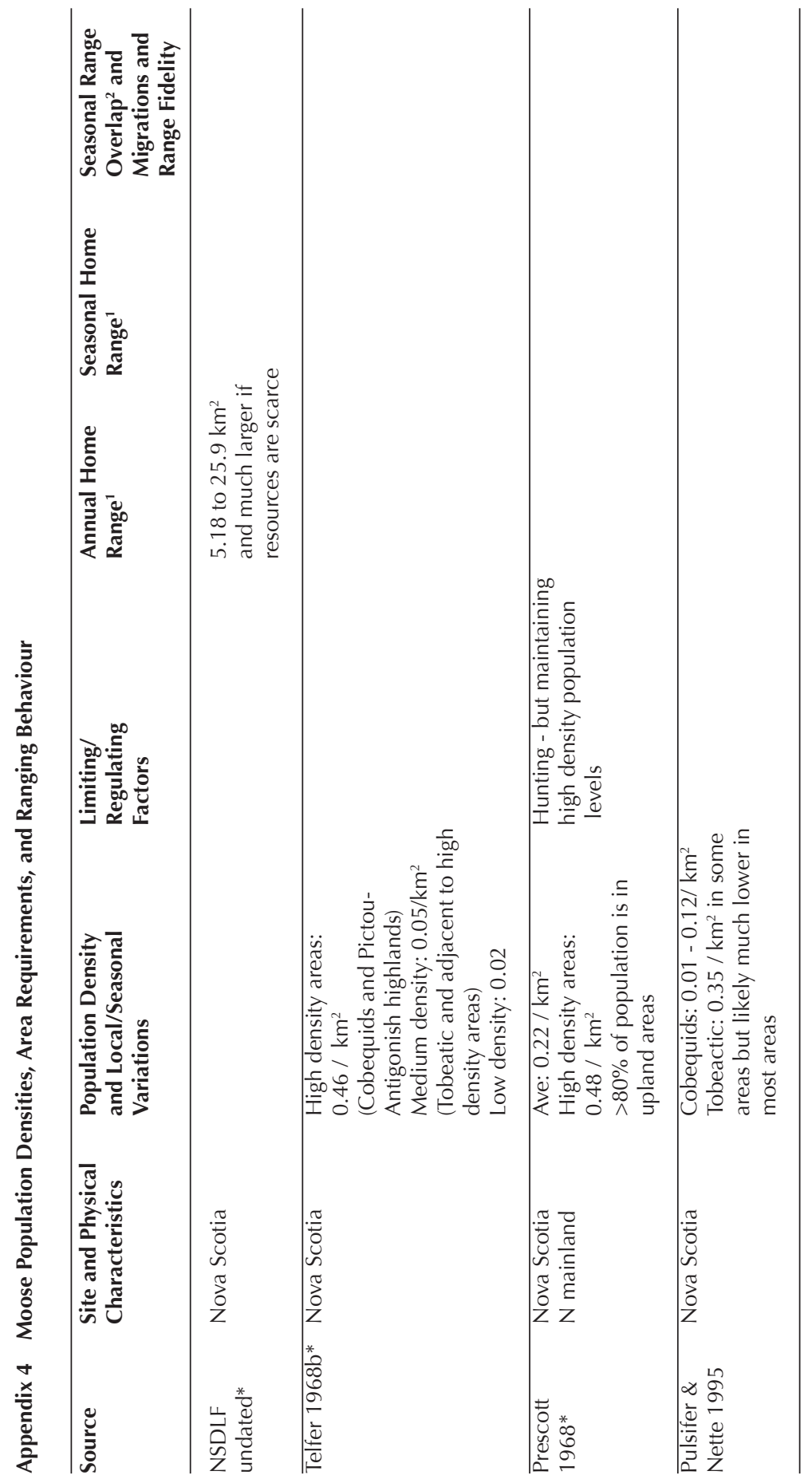




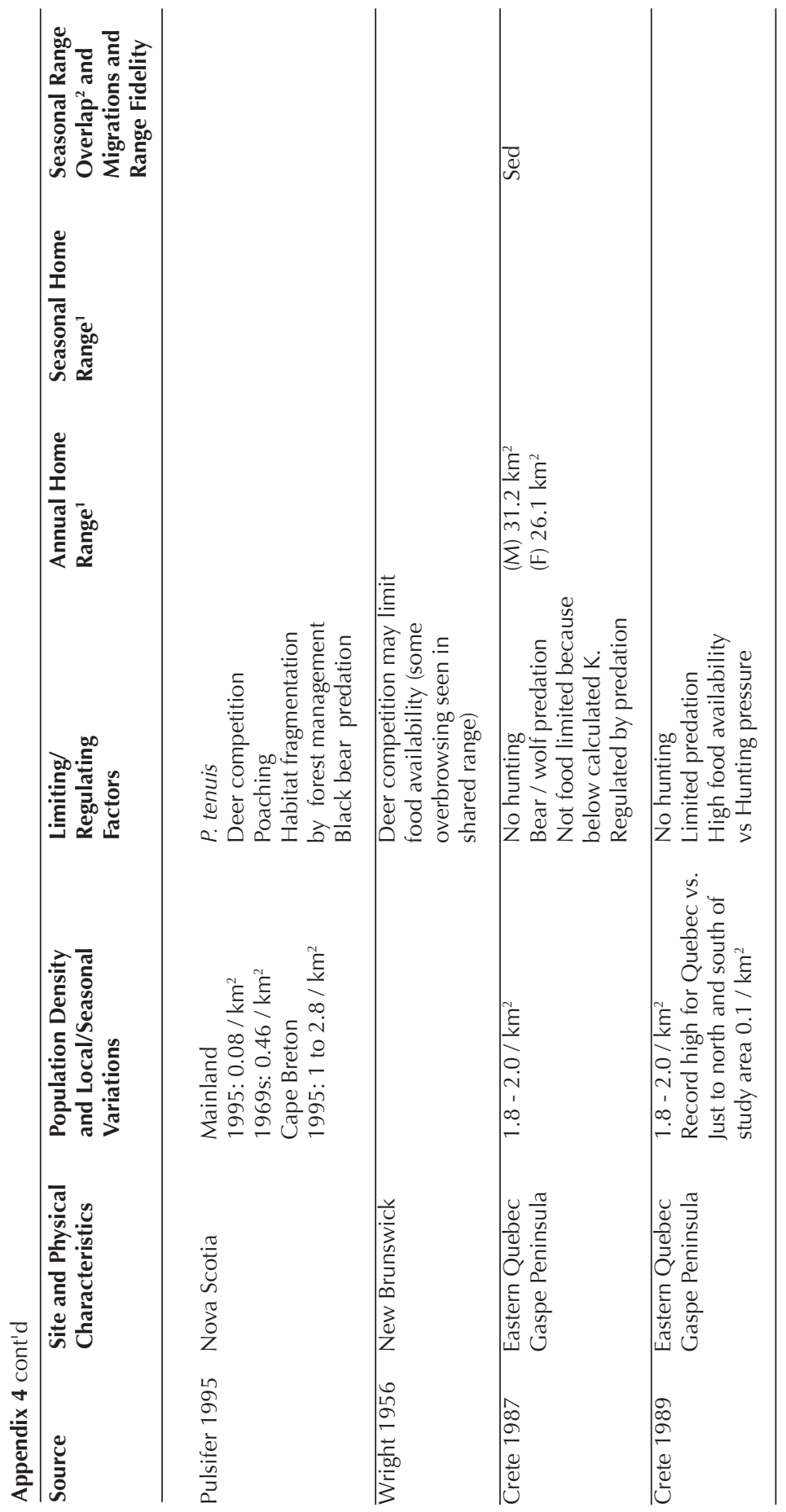




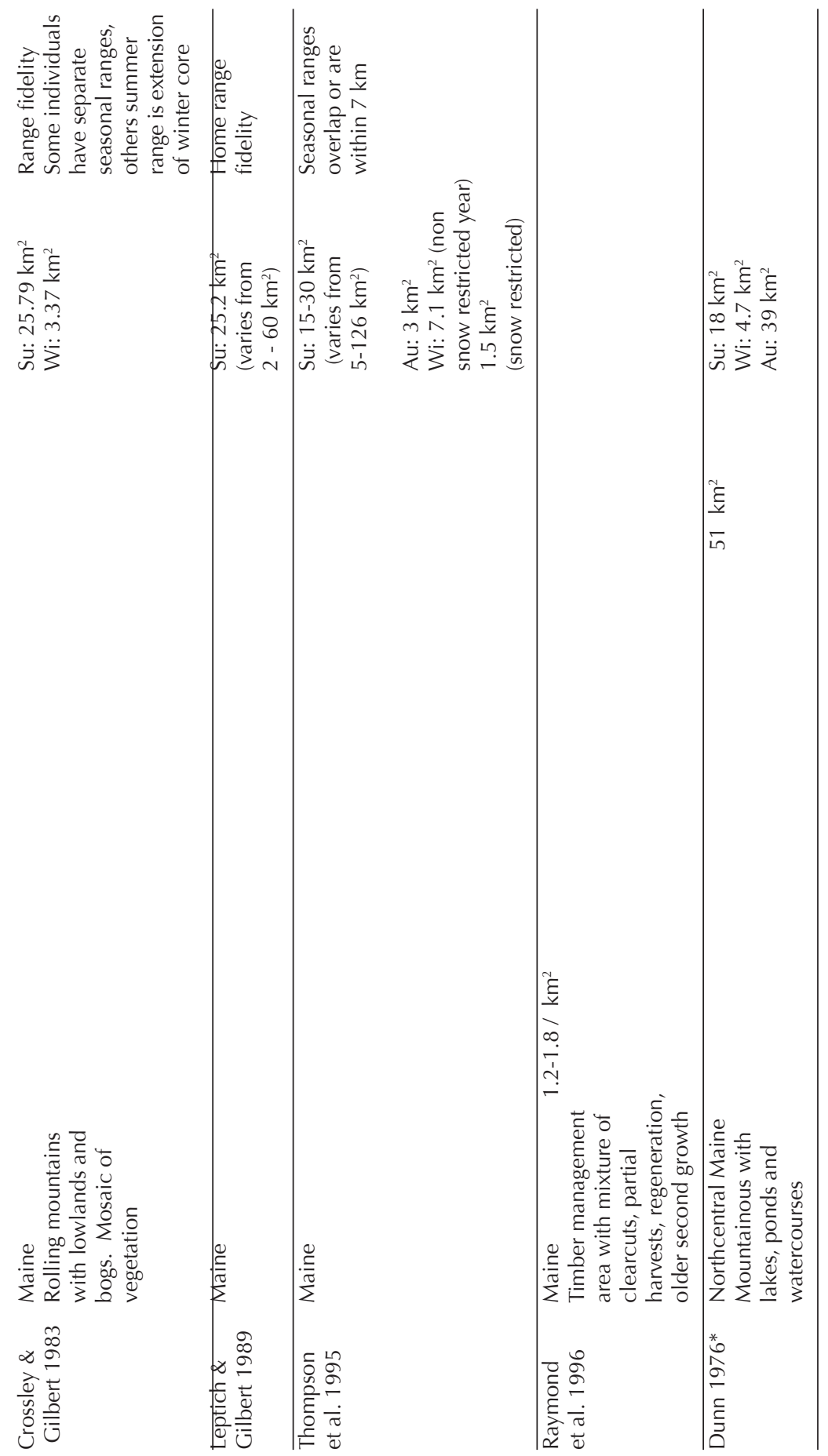




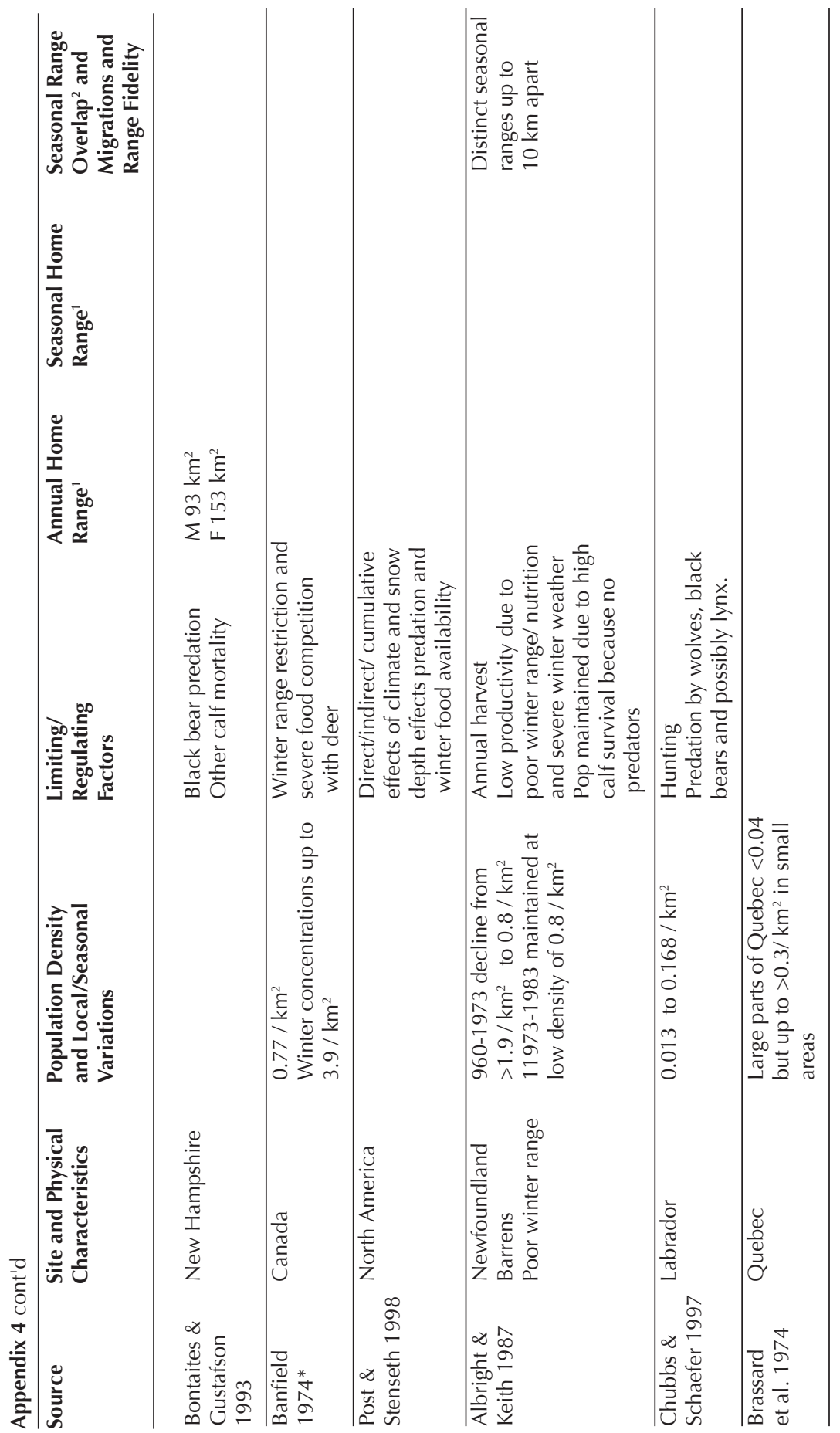




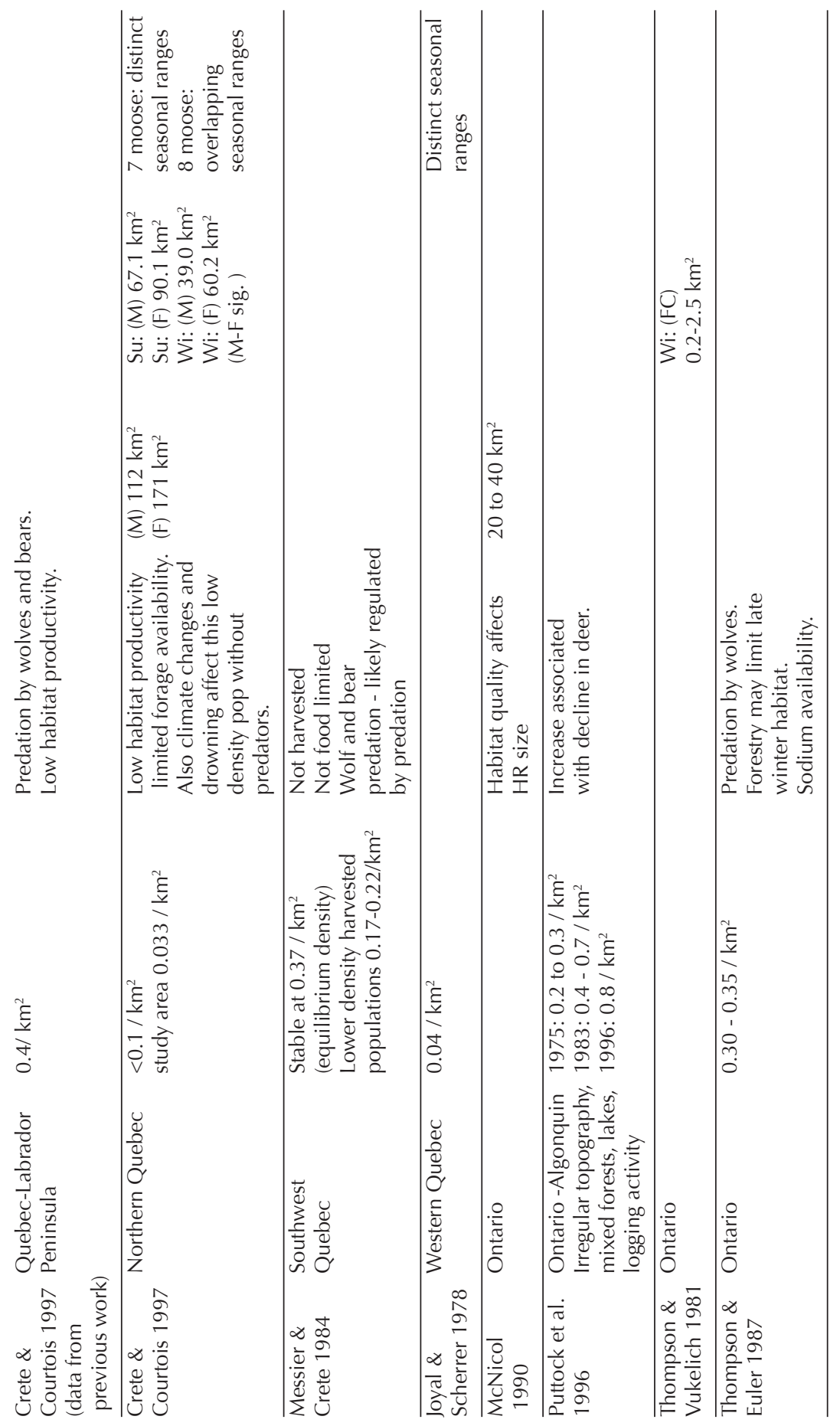




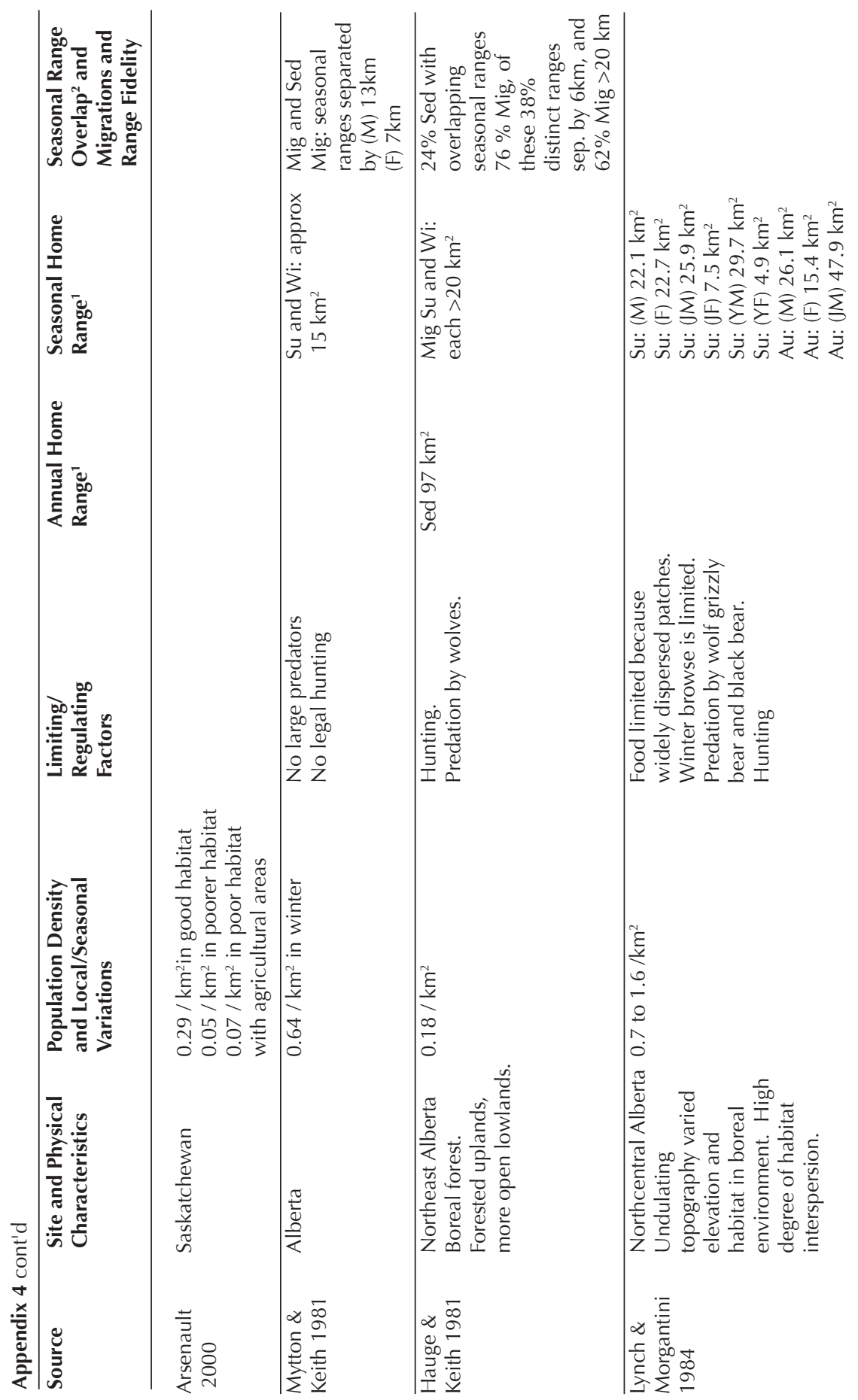




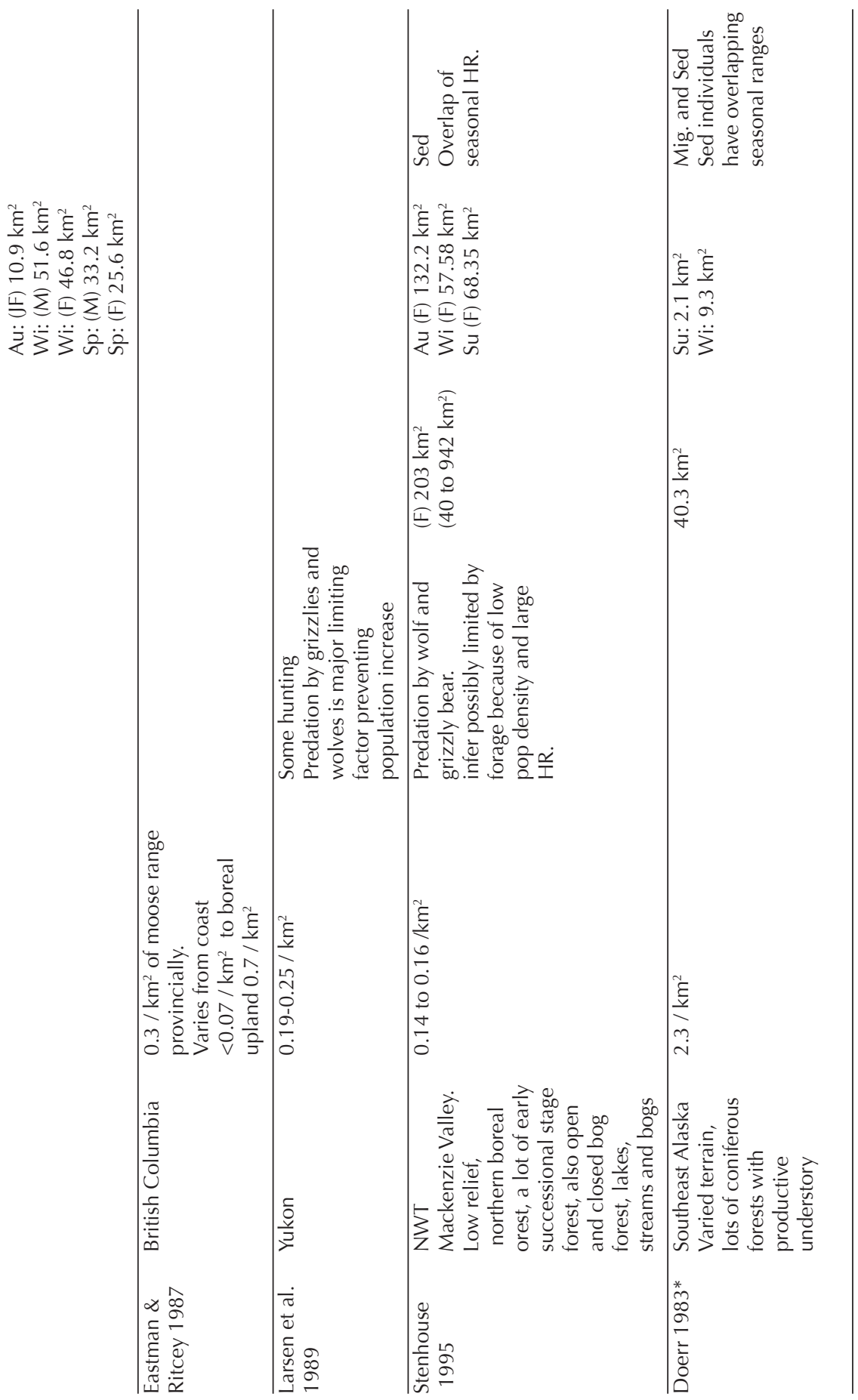




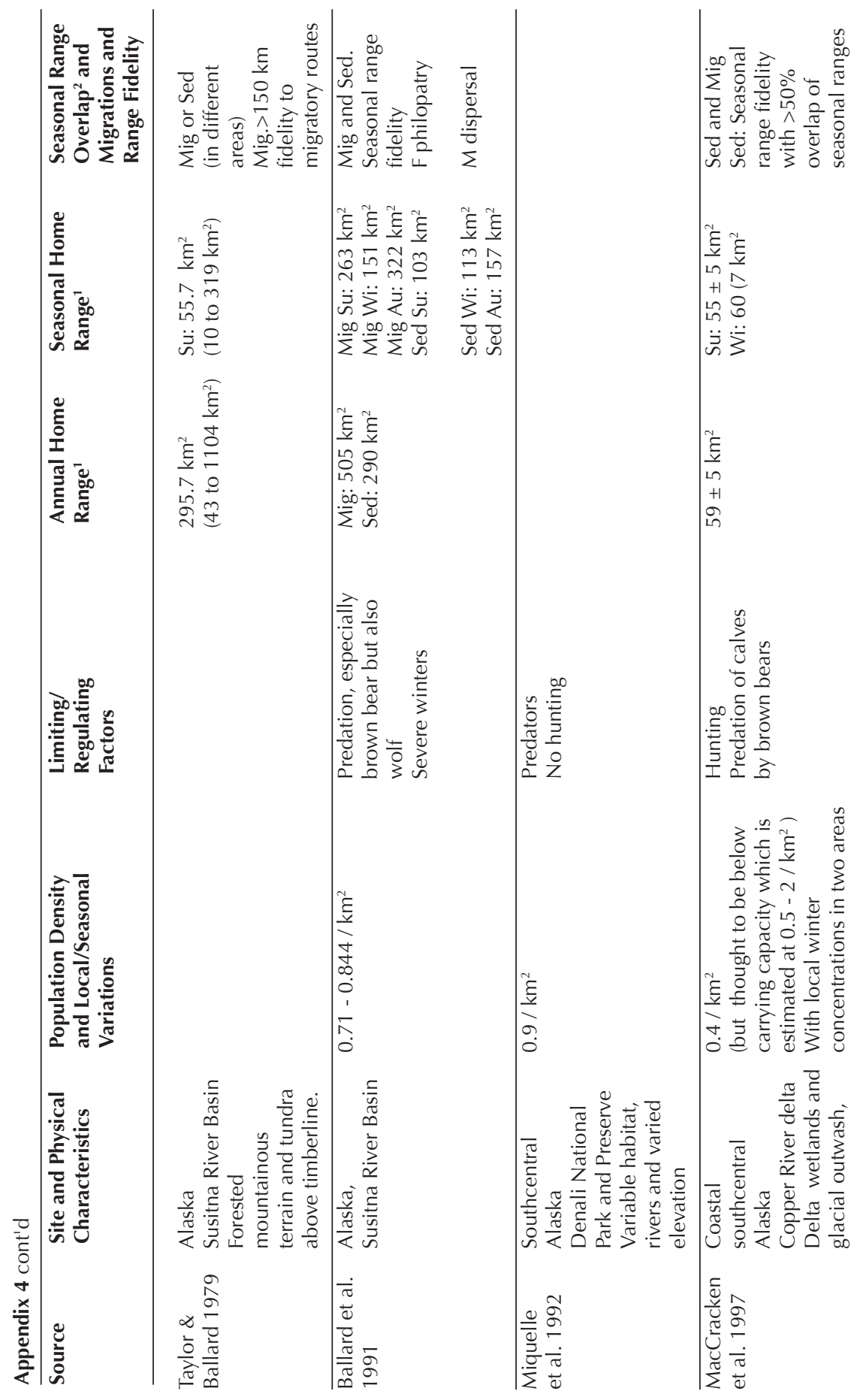



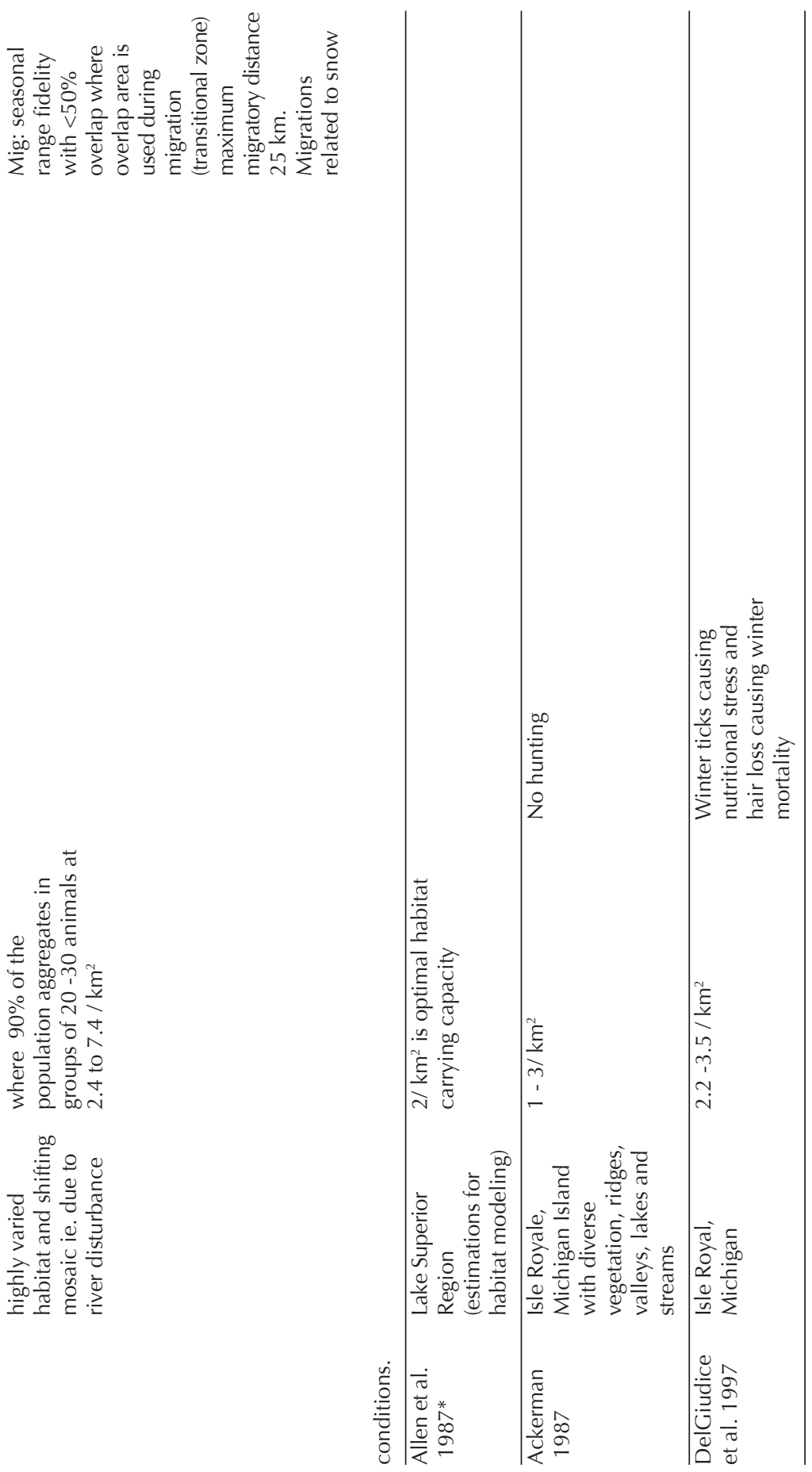


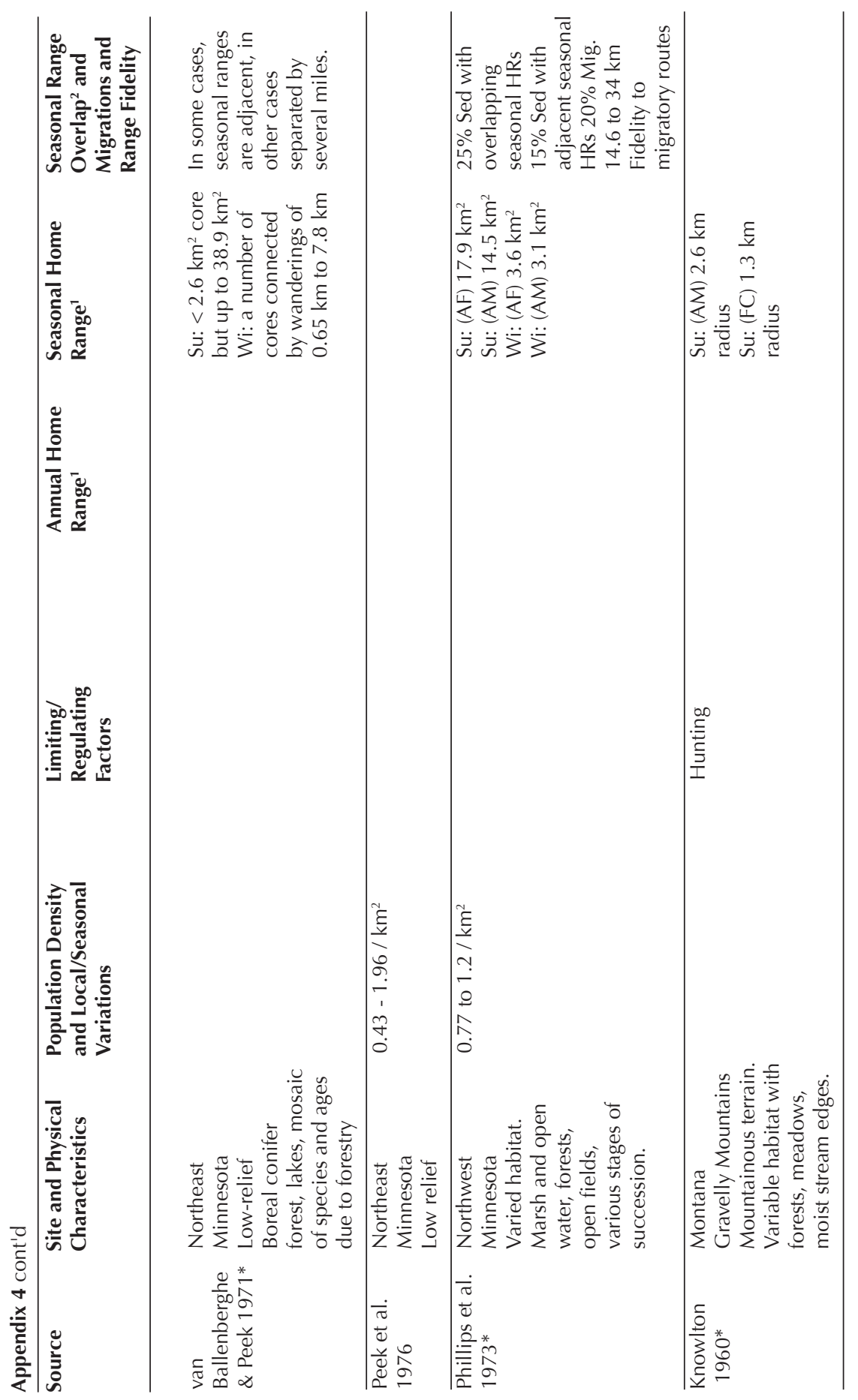




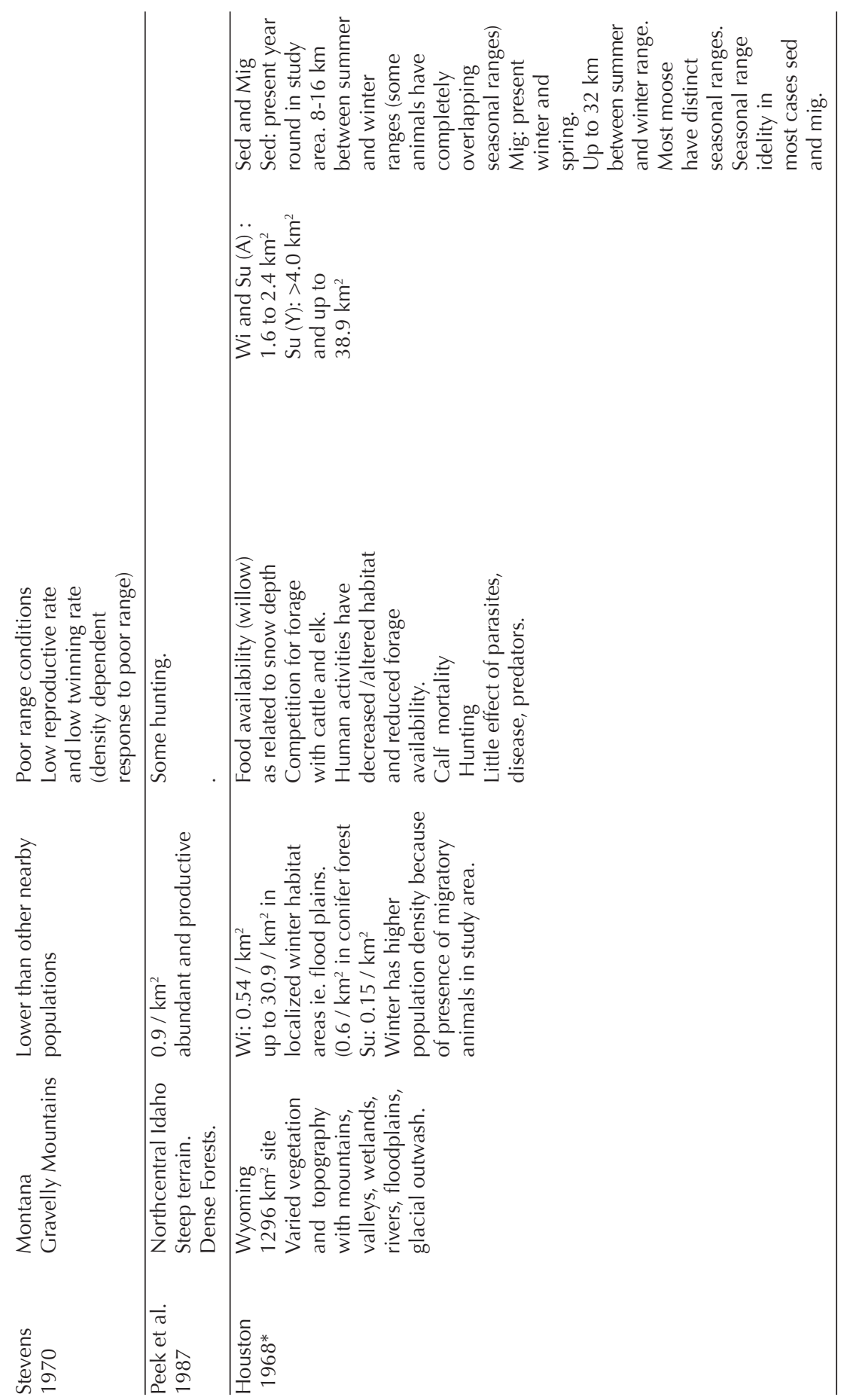




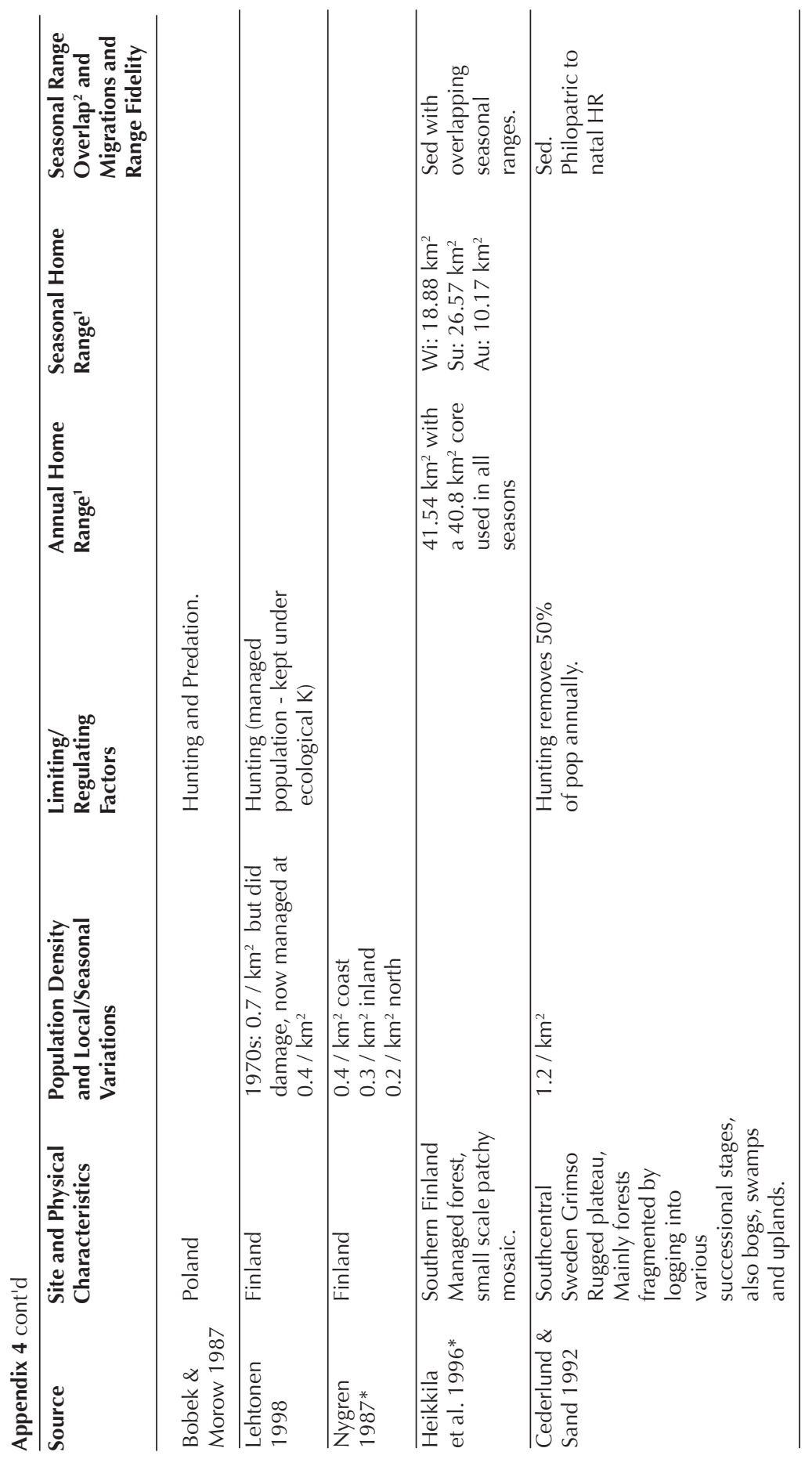




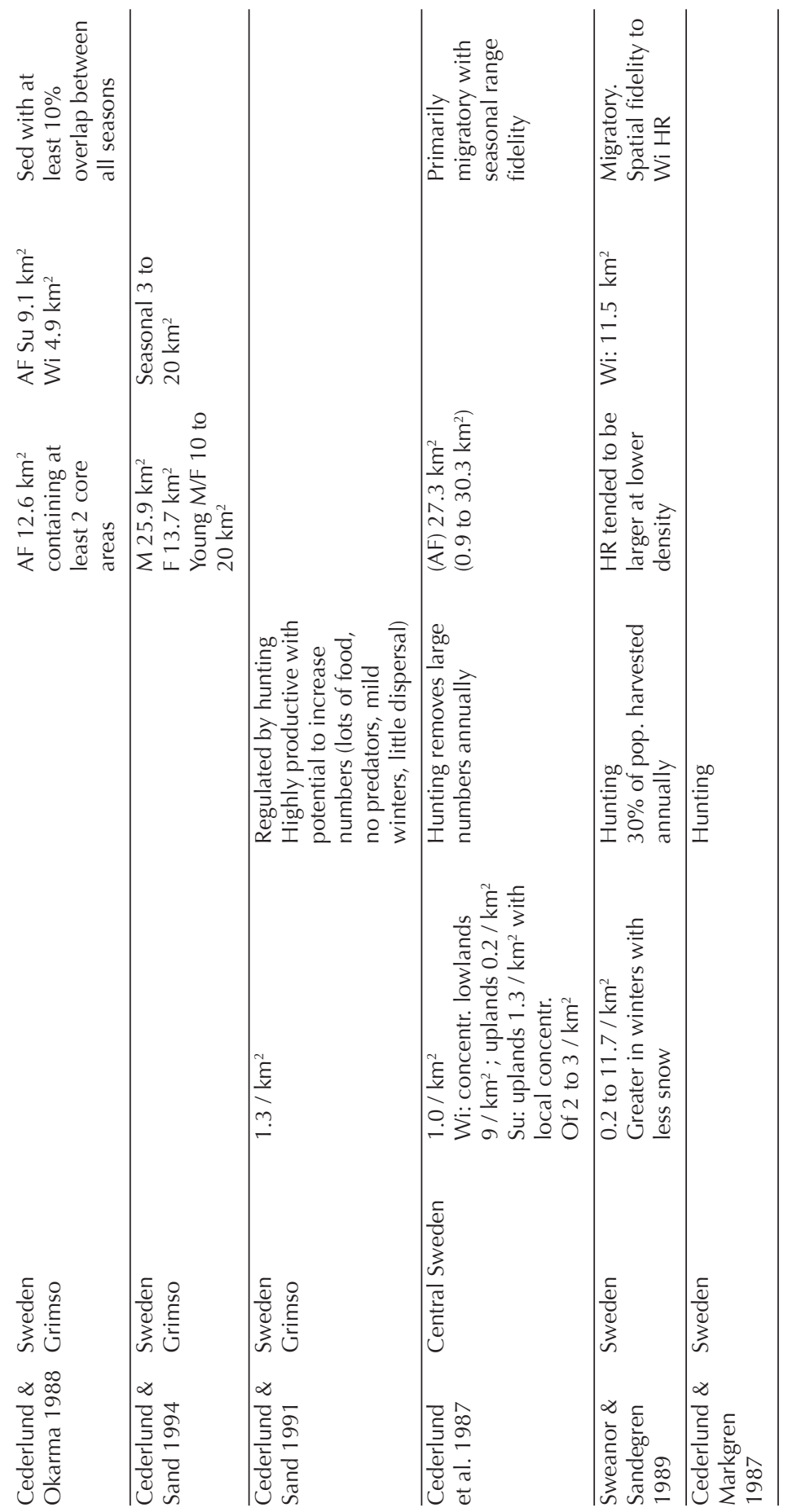




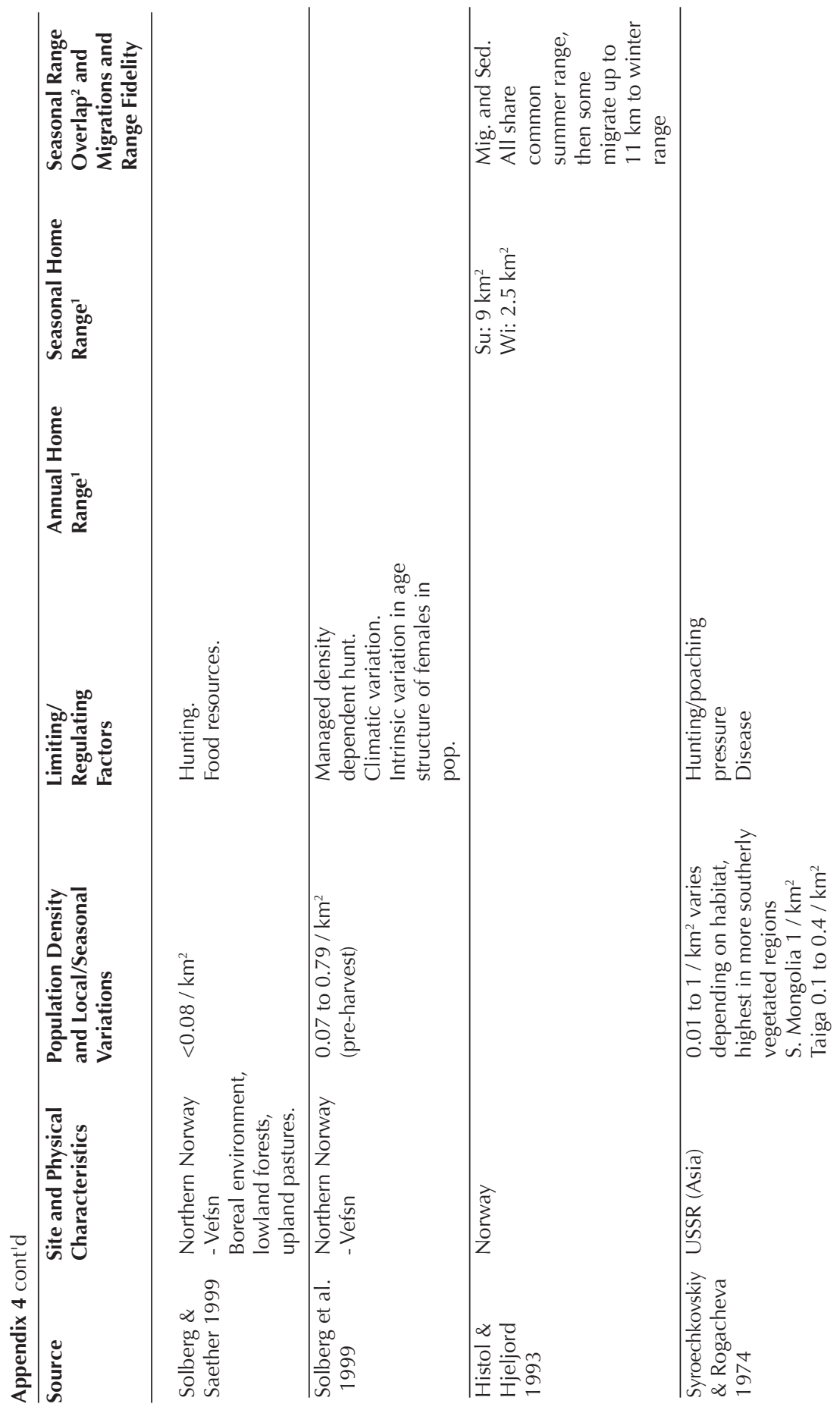



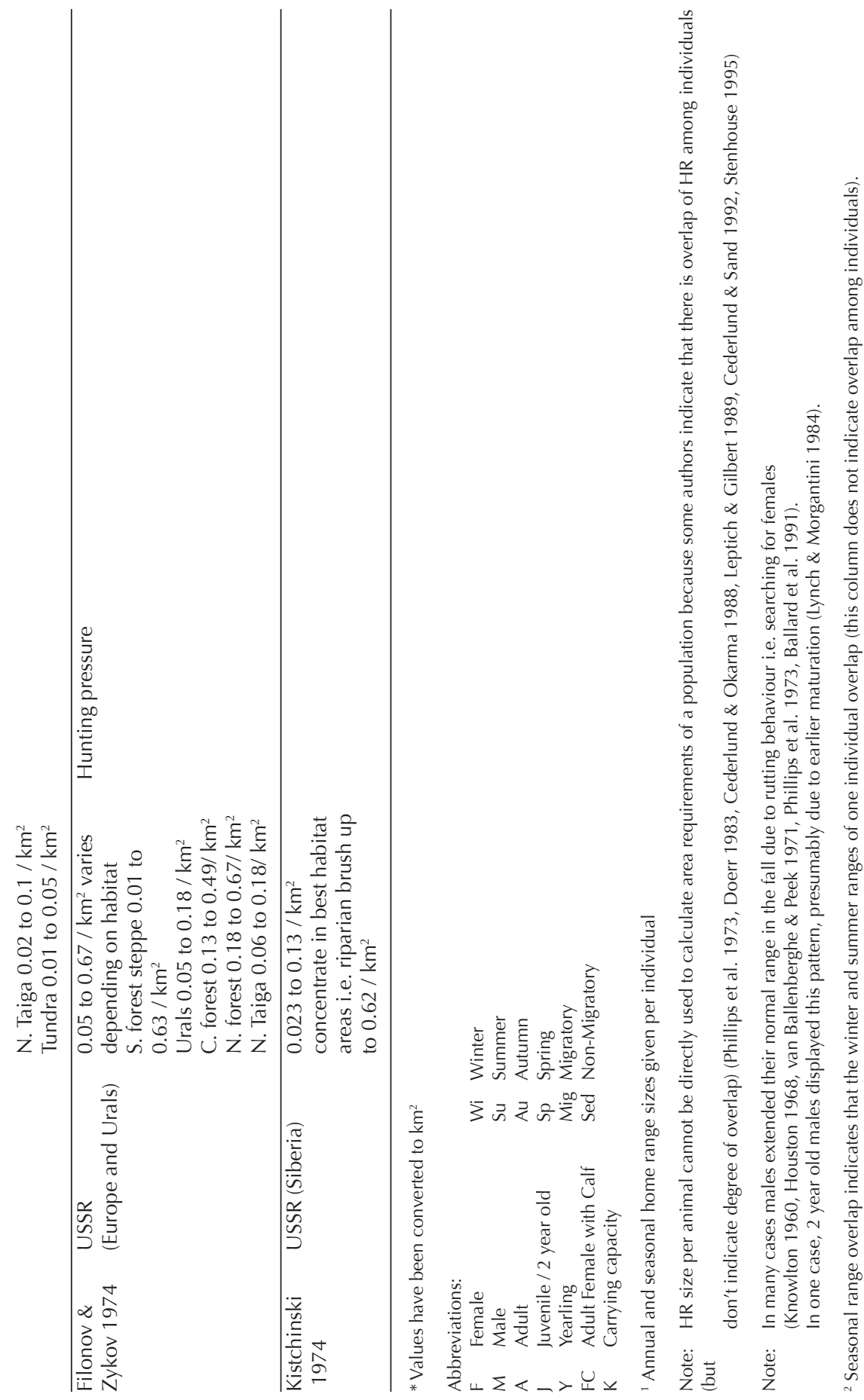